\title{
A drop in the bucket of the megadiverse chewing louse genus Myrsidea (Phthiraptera, Amblycera, Menoponidae): ten new species from Amazonian Brazil
}

\author{
Michel P. Valim ${ }^{1}$ and Jason D. Weckstein ${ }^{2}$ \\ ${ }^{1}$ Museu de Zoologia, Universidade de São Paulo, Ipiranga, São Paulo, Brazil; \\ ${ }^{2}$ Field Museum of Natural History, Department of Science and Education, Chicago, Illinois, USA
}

\begin{abstract}
Ten new species of Myrsidea Waterston, 1915 parasitic on members of the avian families Formicariidae, Thraupidae, Tyrannidae, Troglodytidae and Icteridae are described herein. They and their type hosts are M. isacantha sp. n. ex Chamaeza nobilis Gould, M. circumsternata sp. n. ex Formicarius colma Boddaert (Formicariidae); M. cacioppoi sp. n. ex Lanio fulvus (Boddaert), M. brasiliensis sp. n. ex Tangara chilensis (Vigors), M. saviti sp. n. ex Tangara schrankii (Spix) (Thraupidae), M. rodriguesae sp. n. ex Cnipodectes subbrunneus (Sclater), M. cnemotriccola sp. n. ex Cnemotriccus fuscatus (Wied-Neuwied), M. lathrotriccola sp. n. ex Lathrotriccus euleri (Cabanis) (Tyrannidae), M. faccioae sp. n. ex Cyphorhinus arada transfluvialis (Todd) (Troglodytidae), and M. lampropsaricola sp. n. ex Lampropsar tanagrinus (Spix) (Icteridae). Among these are two new Myrsidea species described from the avian family Formicariidae, which previously had only a single described Myrsidea species, and a new host record for M. cinnamomei Dalgleish et Price, 2005 ex Attila citriniventris Sclater. Analysis of mitochondrial cytochrome oxidase I sequences for these and other neotropical Myrsidea species provides an assessment of their phylogenetic relationships and indicates that all of these newly described species are genetically distinct. We also put these descriptions into context by estimating the potential number of unnamed Myrsidea species in Brazil, given the known diversity of potential hosts and typical levels of host specificity for Myrsidea species. Our estimate indicates that Brazilian Myrsidea species diversity is likely more than an order of magnitude greater than the number of described Myrsidea species known from Brazil, highlighting the need for future work on this megadiverse ectoparasite genus.
\end{abstract}

Keywords: taxonomy, morphology, species diversity, phylogenetic relationships, passerines, Aves, Neotropical region, COI

Parasites can have important impacts on the health, demography, behaviour and evolution of their hosts (Combes 1996, Combes et al. 1996, Parker et al. 2006, Atkinson et al. 2008) and 30-70\% of all named life forms on earth are parasitic (Price 1980, Timm and Clauson 1987, de Meeûs et al. 1998, Windsor 1998, de Meeûs and Renaud 2002), yet we know very little about this important segment of life. Thus, an incredibly high proportion of life that has important consequences to humans, human commensals and wildlife is essentially unknown. The first critical step at understanding this biodiversity is still taxonomic description.

The avian order Passeriformes is the most diverse order of birds. Thus, the extremely host specific (Bueter et al. 2009) chewing louse genus Myrsidea Waterston, 1915 (Amblycera, Menoponidae), which is found almost exclusively parasitizing members of the Passeriformes (Price et al. 2003), is perhaps one of the poster children of parasite diversity. With more than 350 species of Myrsidea described thus far (Sychra et al. 2006, Sychra 2010, Valim et al. 2011), this genus is the most speciose of all genera in the parasitic insect order Phthiraptera and many more remain to be described.

The Brazilian Phthiraptera fauna provides an excellent example. Although the country of Brazil is home to an extremely large diversity of birds ( $c a 1750$ species), including approximately 900 Passeriformes (Dickinson 2003, Lepage 2013), it almost certainly harbours a huge diversity of Myrsidea. However, there are only a few published records of this louse genus for the country (e.g. Guimarães 1944, Oniki 1990, 1999, Valim and Serra-Freire 2003, Valim et al. 2005, 2009, Enout et al. 2009, Sychra et al. 2009). Some of these records are simply identified at the generic level due to a lack of knowledge about which species occur, even on common bird species (Guimarães 1944, Valim et al. 2009, Enout et al. 2009, 2012).

Hyperdiverse yet undocumented parasite groups, such as Myrsidea, are in need of taxonomic description and phylogenetic systematic analysis. Thus, this paper is the beginning of an attempt to reduce the large gap 
of knowledge about the species of Myrsidea found on Brazilian birds. In this paper we describe ten new Myrsidea species and a scheme for this and future taxonomic descriptions of Myrsidea, to ensure that the diagnostic characters used in the descriptions of Myrsidea species are both taxonomically and phylogenetically informative.

Lastly, based on an analysis of published chewing louse host association records (see references below) from potential avian host species found in Brazil, we estimate the potential remaining numbers of undescribed Myrsidea species that are still awaiting description in Brazil. Myrsidea in general are thought to be extremely host specific (e.g. Clay 1966, 1968, Dalgleish and Price 2003, Price et al. 2003, 2004, 2005, 2008a-c, Price and Dalgleish 2006, Bueter et al. 2009, Price and Johnson 2009, Sychra et al. 2009, Valim et al. 2011), and thus it is likely that even these ten new species are only a drop in the bucket of Myrsidea species diversity in Brazil and on the planet.

\section{MATERIALS AND METHODS}

We collected the specimens for this study using the ethyl acetate fumigation technique as described in Clayton and Drown (2001) and modified by Bueter et al. (2009). For all ten of the Myrsidea species described here as new we used the modified technique as described by Valim and Weckstein (2011) to extract DNA and then amplified and sequenced a 379 base pair (bp) fragment of the mitochondrial cytochrome oxidase I (COI) gene. The DNA extracts remaining from these sequences are held at Field Museum of Natural History (FMNH), under the code provided for each DNA voucher code listed in the 'examined specimens'.

In the phylogenetic analysis we also included several previously unpublished COI sequences from named Myrsidea taxa found in Brazil and from all of the Neotropical Myrsidea species previously published in the literature and deposited in GenBank (AF545694, AF545732, EU289211-14, EU650228-29, FJ171267, FJ171272, FJ171278, FJ171281-82, FJ171286-88, FJ171290-91, GQ454448-50, JN638820-22; Johnson et al. 2003, Price et al. 2008a-c, Bueter et al. 2009, Price and Johnson 2009, Valim et al. 2011). All newly generated DNA sequence data and associated voucher numbers and locality data are deposited in GenBank (KF048103-28).

We used PAUP* (version 4.0b10; Swofford 2003) to calculate uncorrected $p$-distances between the COI sequences of all 50 Myrsidea species. To reconstruct the phylogenetic relationships among available COI sequences of Neotropical Myrsidea species and those sequenced for this study, we conducted a maximum likelihood (ML) search and bootstrap analysis of 379 bp of COI from all species plus the outgroup Dennyus hirundinis (Linnaeus, 1761). For the ML search we determined the best fit model for the analysis using jModelTest (Guindon and Gascuel 2003, Posada 2008) and conducted the ML search and bootstrap analysis using Garli v2.0 (Zwickl 2006; see also http://garli.googlecode.com).

We ran five independent search replicates, each beginning at a different starting point, using the model TPM1 uf $+\mathrm{I}+\mathrm{G}$, which includes three classes of nucleotide substitution rates. After the analyses were complete we considered the tree with the best likelihood score to be the best phylogenetic hypothesis. We estimated all model parameters that best fit the data as part of the Garli analysis. We also performed 100 bootstrap replicates with the same model to assess statistical support for nodes in the phylogeny.

We calculated the total known and potential known Myrsidea species and used these figures to estimate the number of undescribed Myrsidea species in Brazil based on an index of host specificity (index of specificity (IS) = Myrsidea species/ host species of Myrsidea). We calculated the index of host specificity from the list of avian hosts found in Brazil from orders and families known to be parasitised by some Myrsidea species, including perching birds (Passeriformes), hummingbirds (Trochilidae) and toucans (Ramphastidae). Dubious records present in literature, e.g. Myrsidea funerea (Kellogg et Chapman, 1899) on Picoides pubescens turati (Malherbe) (Picidae), were not included in the analysis to conservatively avoid overestimating Myrsidea diversity.

We used the Howard and Moore (Dickinson 2003) checklist of birds from Brazil reported by Avibase (Lepage 2013) and the host parasite association data reported in Price et al. (2003) and subsequent papers recently published on this genus (Dalgleish and Price 2003, Price et al. 2004, 2005, 2008a-c, Price and Dalgleish 2006, Price and Johnson 2009, Sychra et al. 2006, 2009, Kounek et al. 2011a,b, Valim et al. 2011). Nineteen bird species listed as incertae sedis in Avibase were not included in the calculations because they were not known to be parasitised by Myrsidea.

All specimens, including the DNA vouchers, were slidemounted using Palma's (1978) Canada balsam method. In the following descriptions, all measurements are in millimetres. Host names are from Dickinson (2003), morphological names for chewing louse structures strictly follow those applied by Clay $(1966,1968,1969,1970)$.

Abbreviations are: ANW, female anus width; AWIV, abdomen width at segment IV; dhs, dorsal head setae (sensu Clay 1969) (Fig. 12); GL, male genitalia length; GSL, male genital sclerite length; HL, head length at midline; $l s 5$, labial seta 5 (sensu Clay 1966) (Fig. 11); MSPL, metasternal plate length; MW, metathorax width; POW, preocular width; PSPL, prosternal plate length; PW, prothorax width; TL, total length; TW, temple width. The ratio of the length of dhs10/dhs11 (rounded to two decimals) was calculated for each individual specimen examined, thus we did not simply use the final minimum and maximum values of the raw setal measurements of all individuals examined to calculate these final ratios.

Measurements of the body features were taken as follows: ANW, from the bases of the most lateral anal seta on each side of the anal fringe; AWIV, from the widest part of plurites IV; $\mathrm{GL}$, at midline, from the most distal part of the mesomere to the visible apices of basal apodeme; GSL, from the distal part of the sclerite to the visible end of its membraneous portion; HL, at midlevel, from the anterior to posterior margins of the head; MW, from the widest part of metanotum at its posterior part; MSPL and PSPL, at their midlevel; POW, at level of $d h s 11$; PW, from the widest part of pronotum; TW, at level of $d h s 29$; TL, at midline, in females considering the posterior margin of the dorsal anal fringe, but not including the setae. 
Throughout, we are providing detailed descriptions of characters with the intention that these descriptions would be useful for coding characters for morphological phylogenetic reconstruction for Myrsidea species. Thus in describing characters we have considered their homologies, instead of providing only setal counts and morphometric data and leaving the diagnostic and descriptive features based exclusively on continuous characters.

To avoid incompatibility between our descriptions and the most recent publications describing new Myrsidea species (e.g. Price et al. 2005, 2008a-c, Price and Dalgleish 2006, Johnson and Price 2009, Sychra et al. 2009, Kounek et al. 2011a,b), we present a detailed scheme including a suite of characters that we, and hopefully others, will analyse and describe in future Myrsidea species descriptions. We emphasize and consider the 20 morphological features used in this paper as the minimum that should be given in a Myrsidea description (Clay 1966).

We also use setal counts as they were employed by Clay (1966) because her system avoids counting setae with constant counts and allows us to better compare characters based on their primary homology rather than solely using characters for differentiating taxa. Thus, the metanotal setal account does not include the most posterolateral setae, which are always constant, and only includes the counts of setae between the most posterolateral setae. In the same way, the tergal setal counts are based only on the variable setae between the postspiracular complex set in tergal plates, which are composed of the postspiracular seta and the lateral seta associated with it $(b$, of Clay 1970).

On tergite I there may or may not be a lateral seta differentiated from the rest of the marginal setae in size and position; therefore, in the counts of the tergo-central setae of segment I all the marginal setae except the postspiracular are included, but in the tergo-central setal counts of segments II-VIII the seta associated ( $b$, see Fig. 21) with the postspiracular seta are also excluded as proposed by Clay (1966). When an anterior row of setae on each tergite is present, those are reported in parentheses after the account for the posterior tergal setae. In the anterior sternal setal count, the two pairs of anterolateral setae on sternite II (setae $a$ of Clay 1966, see Figs. 13 and 20), which are constant in Myrsidea species, are excluded. Sternal setal counts for the III-VI (females) and III-VII (males) include the posterior row plus the lateral patches of setae. When an anterior row is present the most posterior row is presented followed by the anterior count (which includes brushes plus anterior setae) in parentheses.

We believe that using Clay's (1966) standardized system for treating Myrsidea will help researchers more rapidly compare and describe related species from megadiverse areas. More importantly, Clay's (1966) model was developed using a phylogenetic perspective and thus not only did she re-describe and describe new species, but she also coded phylogenetically informative characters for these taxa. Thus by adopting Clay's (1966) model, over time we will continue to construct a large morphological dataset for phylogenetic analysis of this megadiverse group.

Type specimens as well as the DNA vouchers herein described are deposited in the Ectoparasite Collection of the Museu de Zoologia da Universidade de São Paulo (MZUSP), São
Paulo, Brazil, and in the Insect Collection of the Field Museum of Natural History (FMNH), Chicago, USA.

\section{RESULTS}

Phthiraptera Haeckel, 1896

\section{Amblycera Kellogg, 1896}

Menoponidae Mjöberg, 1910

\section{Myrsidea Waterston, 1915}

Entomol. Mo. Mag. 51: 12. Type species: Myrsidea victrix Waterston, 1915 by original designation.

Synonyms:

Acolpocephalum Ewing, 1927. J. Washington Acad. Sci. 17 (4): 88; type: Acolpocephalum brevipes Ewing, 1927 (= Myrsidea brevipes) Alcediniphilus Ansari, 1951. Proc. Nat. Inst. Sci. India 17 (2): 189; type Myrsidea (Alcediniphilus) kuluensis Ansari, 1951 (= Myrsidea sultanpurensis Ansari, 1951)

Allomyrsidea Conci, 1942. Boll. Soc. Entomol. Ital. 74 (2-3): 31; type: Myrsidea struthidea Thompson, 1939

Australmenopon Conci, 1942. Boll. Soc. Entomol. Ital. 74 (2-3): 30; type: Menopon cinerea Thompson, 1939 (= Myrsidea cinerea) Corvomenopon Conci, 1942. Boll. Soc. Entomol. Ital. 74 (2-3): 31; type: Menopon robsoni Cummings, 1914 (= Myrsidea robsoni) Densidea Złotorzycka, 1964. Acta Parasitol. Pol. 12 (17): 171; type: Menopon rusticum Giebel, 1874 (= Myrsidea rustica) Eichlerinopon Złotorzycka, 1964. Acta Parasitol. Pol. 12(17): 179; type: Eichlerinopon celeripes Złotorzycka, 1964 [= Myrsidea cornicis (De Geer, 1778)]

Lanimenopon Złotorzycka, 1964. Acta Parasitol. Pol. 12 (17): 177; type: Lanimenopon abhorrens Złotorzycka, 1964 (= Myrsidea abhorrens)

Liquidea Złotorzycka, 1964. Acta Parasitol. Pol. 12 (17): 173; type:

Liquidea proterva Złotorzycka, 1964 (= Myrsidea proterva)

Myrsidella Eichler, 1951. Zool. Anz. 146: 49; type: Menopon consimile Piaget, 1885 [= Myrsidea cornicis (De Geer, 1778)]

Neomyrsidella Złotorzycka, 1964. Acta Parasitol. Pol. 12 (17): 182; type: $N$. usitata Złotorzycka, 1964 [= Myrsidea anathorax (Nitzsch in Giebel, 1866)]

Vulgidea Złotorzycka, 1964. Acta Parasitol. Pol. 12 (17): 172; type: Menopon cucullare Nitzsch, 1818 (= Myrsidea cucullaris)

Wolfdietrichia Złotorzycka, 1973. Lounais-Hämeen Luonto 46: 51; type: Myrsidea (Wolfdietrichia) cornicis (De Geer, 1778) (= Myrsidea cornicis)

Although Clayton et al. (1992) published the first records of Myrsidea sp. from Formicariidae, only one species of Myrsidea has been described from Formicariidae until now: M. klimesi Sychra, 2006 ex Formicarius analis (d'Orbigny et Lafresnaye). Therefore, here we provide the diagnostic characters that are of significance in defining the genus as it pertains to the species of Myrsidea parasitizing the avian family Formicariidae.

We add morphological characters to define this group of species, based on three species parasitizing this host family, the two newly described herein, plus $M$. klimesi previously described by Sychra in Sychra et al. (2006). Some of these characters will not be repeated in the species descriptions.

Clay (1966) thoroughly characterized this genus. The diagnostic characters for the Myrsidea species found on other bird families can be found in Price et al. (2005) for the Tyrannidae, in Price and Dalgleish (2006), Price and Johnson (2009), Sychra et al. (2009) for Thraupidae, in Price et al. (2008a) for Troglodytidae, and in Clay (1968) for Icteridae. These will be not repeated herein. 


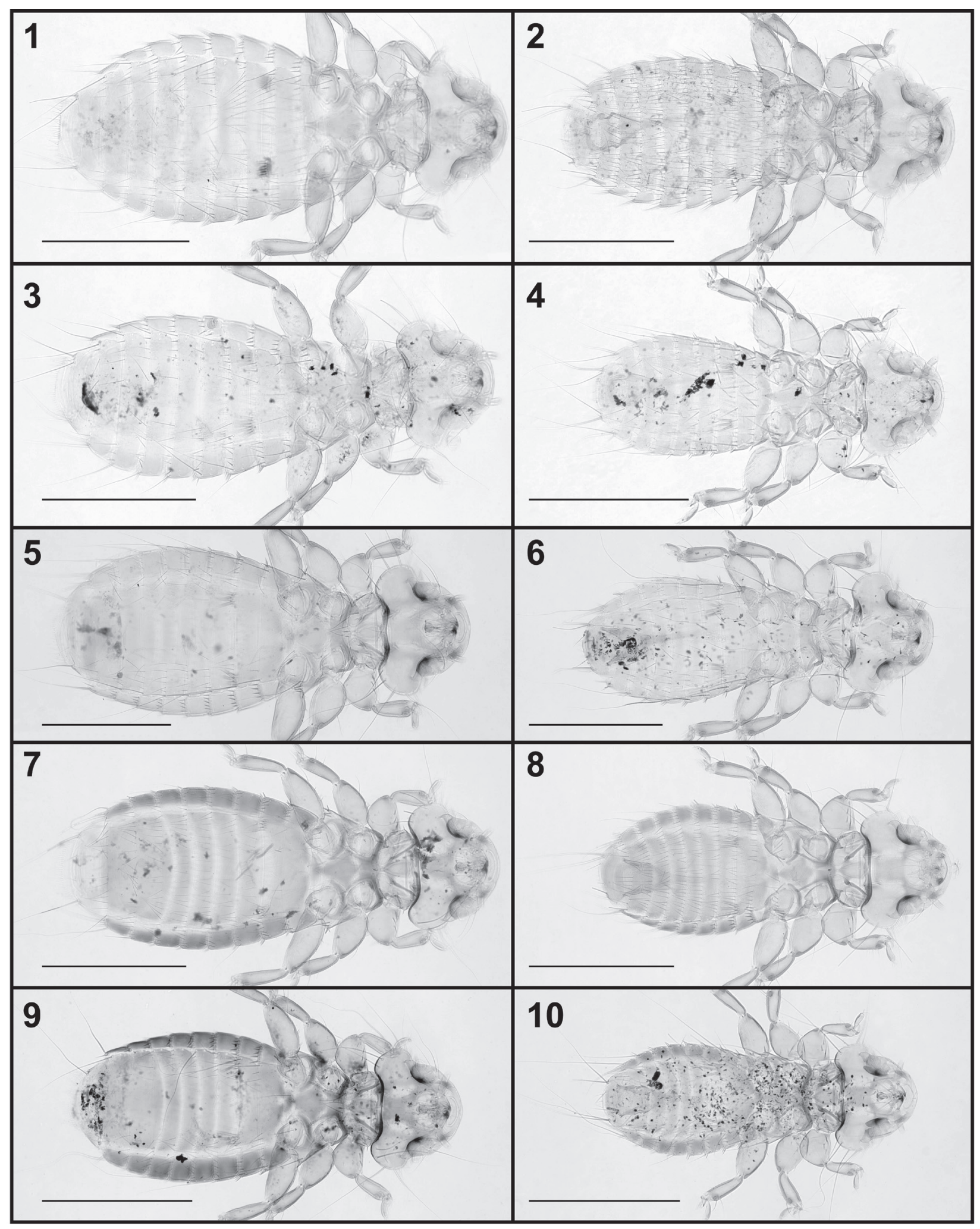

Figs. 1-10. Habitus in dorsal view. Females in left column, males in right column. Figs. 1, 2. Myrsidea isacantha sp. n. Figs. 3, 4. $M$. circumsternata sp. n. Figs. 5, 6. $M$. cacioppoi sp. n. Figs. 7, 8. M. brasiliensis sp. n. Figs. 9, 10. M. saviti sp. n. Scale bars $=0.5 \mathrm{~mm}$. 


\section{Species from Formicariidae}

Major reviews: Sychra et al. (2006), present study.

Head evenly rounded anteriorly; lacking lateral slit or notch; with long inner (dhs21) and outer (dhs22) occipital setae, both surpassing pronotal carina (Fig. 12); dhs23 present and set anterolateral to dhs22 (Fig. 12); gula usually with 4 setae on each side, less often 3 only on one side, with heavier longer posterior seta; hypopharyngeal sclerite reduced (Fig. 14).

Thorax with pronotum bearing a pair of minute central setae (dps2) (Fig. 12) (also in M. klimesi ?); with 3 setae at each lateral angle and 7-11 longer posterior marginal setae. Mesonotum without median division, but with a Y-shaped line just below postnotum, not forming a suture or even splitting mesonotum. This Y-shaped line slightly less evident, but also discernible in good specimens from other host families. Mesonotum of M. klimesi supposedly divided medially. Metanotum without central setae, but with 3 short setae around anterolateral margins on each side. Metapleura with 3 short spine-like setae. Prosternal plate well developed, elongate, with 2 short anterior setae (like in M. klimesi, see Sychra et al. 2006); metasternal plate prominent, diamond shaped with its posterior angle at least reaching middle of sternite I, usually with 11 setae, much less often 12, or 14 .

Abdomen with undivided tergites, apparently without anterior setae except for very small seta at corner of each side of tergite I (not included in tergal count), but in males of one species anterior row of setae present on I-VI; sternite I medium sized, mostly surrounded by sternite II, apparently without setae (except for one male of $M$. isacantha sp. n.); sternite II enlarged, with aster of heavy setae at each posterior corner (Fig. 13). Sternite VII fused with VIII + IX + X, forming female subgenital plate, although with a distinct transverse fenestra distinctly enclosed at lateral sides of subgenital plate where seventh and eighth segments fused (Fig. 11). Sternite VII supposedly distinct from remaining subgenital plate in M. klimesi (Sychra et al. 2006). Female anus oval, without inner setae; subgenital plate of fused sternites VII-IX, vulva with posterior margin smooth. Male subgenital plate of fused sternites VIII-IX; genitalia of usual shape for genus (Fig. 20), with spinous sac having distinctively shaped associated sclerite. Male genital sclerite reduced to two roughly serrated or spiculated lateral arms (Figs. 18, 19).

In summary of the characters listed above, the combination of presence of $d h s 23$ and $d p s 2$, plus $d h s 22$ being as long as $d h s 21$, make the species parasitizing Formicariidae unique among the Myrsidea species named thus far.

Myrsidea isacantha sp. n. Figs. 1, 2, 11, 12, 16, 18, 20, 21

Female. Habitus as in Figs. 1 and 11 and head shape as in Fig. 1. Dorsal head seta 10, 0.026-0.029 long; dhs11, $0.106-0.126$ long, ratio dhs 10/11 0.206-0.274. Hypophar- ynx reduced (as in Fig. 14), ls5 0.03-0.05, ventrolateral fringe, 9-10 setae. Gula with 4 setae on each side. First tibia with 4 outer lateral ventral and dorsal setae. Metanotum with posterior margin straight and with 7-10 setae on posterior margin, metasternal plate with 11-14 setae (as in Fig. 16). Setae of femoral brush, 15-17. Metanotum and abdomen as in Fig. 11. Tergites I-III straight on posterior margin, with a continuous tergal setal row. Small central gap discernible in each tergal setal row of segments IV-VIII. Tergal setae: I, 16-20; II, 22; III, 19-24; IV, 17-20; V, 15-17; VI, 11-14; VII, 8-11; VIII, 5-6. Tergites III and IV with $1+1$ anterior setae in one paratype only. Postspiracular setae shortest $(0.19-0.25)$ on I, II, III and VI, and long (0.27-0.37) on IV, V, VII and VIII.

Sternal setae: I, 0 ; II, each aster of 6 setae (one paratype with 5 and 7 on each side, respectively), posterior margin with 15 and anteriorly with 18-21; III, 29-33 (20-22); IV, 29-31 (14-17); V, 26-33 (15-19); VI, 24-33 (15-22); VII, 16-20 (17-20); VIII-IX, 31-41; vulvar margin with 10-14 setae. Each pleurite (III-VII) with about 5-6 short marginal setae; presence of 1-2 anterior setae on pleurites III-VII; pleurite VIII as in Fig. 15. Tergite IX with inner posterior setae set near lateral margin of last tergite, 0.03-0.04 long (Fig. 11). Anus with 38-39 ventral fringe setae, 37-38 dorsal. Dimensions $(n=3)$ : TW, 0.47-0.48; POW, 0.35-0.36; HL, 0.28-0.30; PW, 0.29-0.33; PSPL, 0.11-0.12; MW, 0.44-0.48; MSPL, 0.21-0.23; AWIV, 0.60-0.69; ANW, 0.21-0.23; TL, 1.55-1.58.

Male. Much as in female, habitus as in Fig. 2. Gular plate with 4 setae on each side. Metanotum with 10-11 setae on posterior margin. Setae of femoral brush, 16-18. Anterior setae present on tergites I-VII. Tergal setae: I, 20-24 (1-4); II, 24-29 (10-14); III, 27-30 (14-17); IV, 25-30 (11-22); V, 23-32 (9-11); VI, 23-25 (4-8); VII, 22-24 (7); VIII, 16-17. Without median gap in each tergal setal row; tergal setae of similar length reaching alveoli of next tergal row. Postspiracular setae as for female. Pattern of chaetotaxy of tergites $\mathrm{V}-\mathrm{IX}+\mathrm{X}$ as in Fig. 21.

Sternal setae: I, 0 (one paratype with 1 seta); II, each aster of 3-5 setae, posterior margin with 12-15 and anteriorly with 16-19; III, 26-34 (16-19); IV, 25-33 (17-18); V, 23-40 (13-24); VI, 24-30 (19-21); VII, 17-24 (18-24); VIII, 45-50. Tergite IX with inner posterior setae set near lateral margin of last tergite, 0.02-0.03 long (Fig. 21), except one paratype with 1 additional seta only on one side, 0.06 long. Anus with 8 internal setae on ventral side and 3 on dorsal. Genitalia and genital sac sclerite as in Figs. 20 and 18, respectively. Dimensions $(\mathrm{n}=3)$ : TW, 0.45-0.47; POW, 0.34-0.35; HL, 0.27-0.28; PW, 0.30; PSPL, 0.11; MW, 0.38-0.40; MSPL, 0.17-0.19; AWIV, 0.50-0.53; GL, 0.36-0.40; GSL, 0.08-0.09; TL, 1.33-1.37.

Type host: Chamaeza nobilis Gould - striated antthrush (Formicariidae).

Ty p e 1 o c a lity: Rio Acanauí, Japurá, Amazonas State, Brazil (0201'38"S; 66040'28"W). 


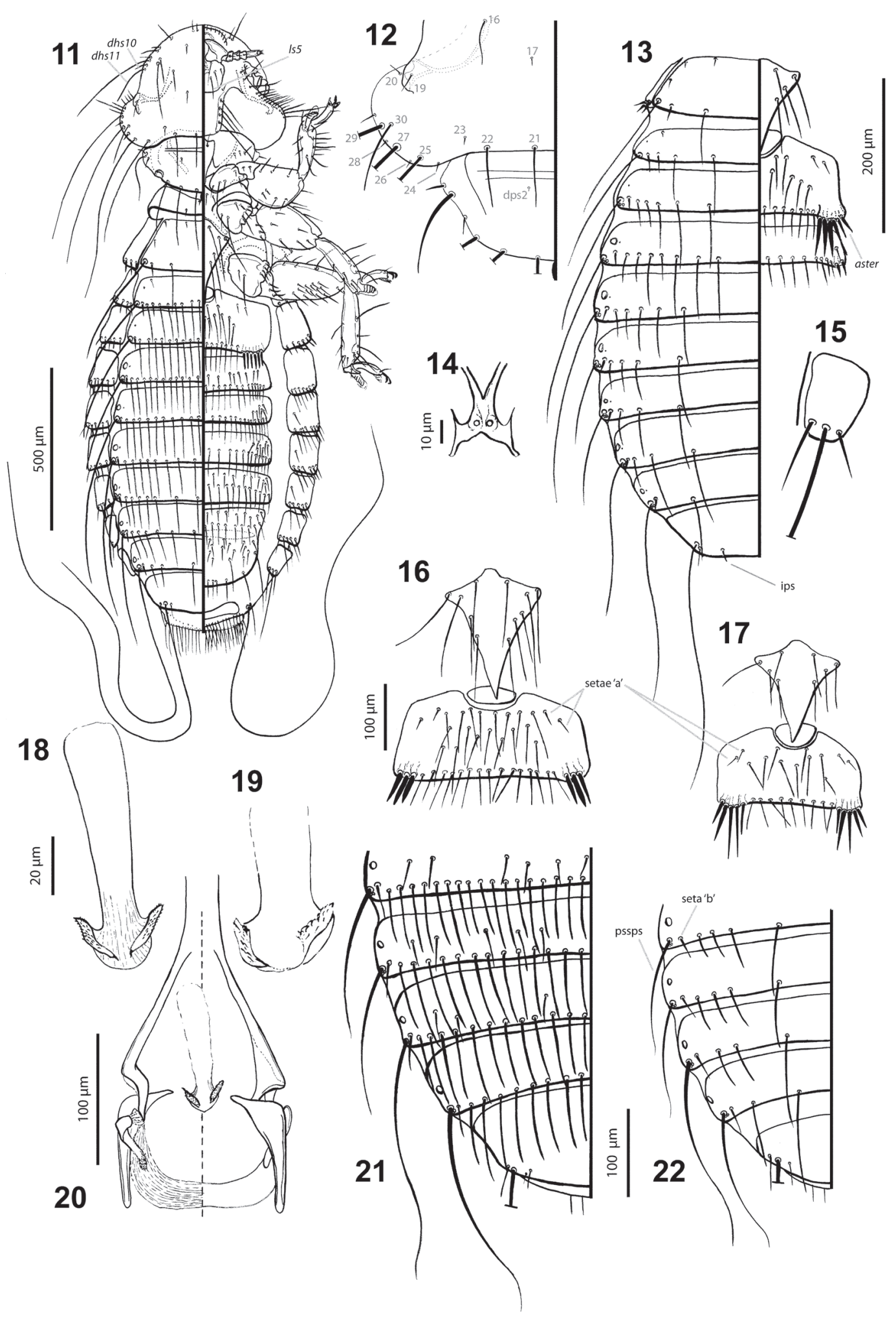

Figs. 11, 12, 16, 18, 20, 21. Myrsidea isacantha sp. n. Fig. 11. Entire female, dorsoventral view. Fig. 12. Temporal and occipital chaetotaxy, plus the dorsal pronotal surface (dhs 16-30). Fig. 16. Metasternal, sternal I and II plates. Fig. 18. Male genital sclerite. Fig. 20. Male genitalia, in dorsoventral view. Fig. 21. Tergites V-IX + X of male. Figs. 13-15, 17, 19, 22. M. circumsternata sp. n. Fig. 13. Female metanotum and dorsal abdomen. Fig. 14. Female hypopharynx. Fig. 15. Pleurite VIII of female. Fig. 17. Metasternal, sternal I and II plates. Fig. 19. Male genital sclerite. Fig. 22. Tergites V-IX + X of male. Abbreviations: aster - patch of spine-like setae on sternite II; dhs 10 and $d h s 11$ - dorsal head setae 10 and 11 ; dps - dorsal pronotal seta; ips - inner posterior seta; ls 5 - labial seta 5; pssps - post-spiracular seta; setae ' $a$ ' - anterior lateral setae of sternite II; setae ' $b$ ' - lateral seta associated with post-spiracular seta. 
Type material: Holotype female (MZUSP 2310), ex Chamaeza nobilis, JAP341 MPEG 62964; Rio Acanauí, Município Japurá, Amazonas, Brazil, 18 July 2007, collected by J.D. Weckstein. Paratypes: three males and two females, same data as the holotype. Coll. Nos.: one male (FMNH-INS 94000) and one female (FMNH-INS 94001, DNA voucher Mysp.Chno.1.4.2011.4); two males (MZUSP 2312, 2313) and one female (MZUSP 2311).

Etymology: Composed by iso- (= equal in Greek), and -acanthus (= spine in Greek), which refers to the size and shape for spine-like setae that compose the aster on sternite II.

Diagnosis. Distinct from other groups of Myrsidea by the characters provided above. Its distinctive feature is the even length and comb-like shape of the spine-like setae on the aster of sternite II. The comb-like shape of the setal aster of sternite II is so far unknown for other Brazilian or Neotropical species of Myrsidea.

Myrsidea isacantha sp. n. is morphologically and genetically close to $M$. circumsternata sp. n., and also morphologically close to M. klimesi, but is distinguished from them by shape and chaetotaxy of sternites II, including the aster and elevated number of metasternal, tergal and sternal setae; in males the tergal plates have a distinct anterior row of setae on I-VII (absent in M. klimesi and M. circumsternata sp. n.).

Myrsidea circumsternata sp. n. Figs. 3, 4, 13-15, 17, 19, 22

Female. Habitus and head shape as in Fig. 3. Dorsal head seta 10, 0.022-0.027 long; dhs11, 0.096-0.112 long, ratio $d h s 10 / 11 \quad 0.194-0.241$. Hypopharynx reduced (Fig. 14), ls5 0.02-0.03, ventrolateral fringe, 8-9 setae. Gula with 4 setae on each side. First tibia with 3 and 4 outer lateral ventral and dorsal setae, respectively. Metanotum with posterior margin straight and 4 setae on posterior margin, metasternal plate with 8-9 setae (as in Fig. 17). Setae of femoral brush, 11-13. Metanotum and abdomen as in Fig. 13. Tergites I-III straight on posterior margin. With a median gap in each tergal setal row of the segments I-VIII. Tergal setae: I, 7-10; II, 8-10; III, 10-11; IV, 8-9; V, 8; VI, 6-8; VII, 6-7; VIII, 4. Postspiracular setae shortest $(0.14-0.18)$ on V, VI and long $(0.25-0.40)$ on I, II, III, IV, VII and VIII.

Anterior row of setae present on sternites; sternite III with reminiscent aster, weak and discrete, composed by 2-3 spine-like setae, each side, arising from an indistinct tubercle (these setae included in sternite III setal account). Sternal setae: I, 0; II, each aster of 4-6 setae, posterior margin with 11-13 and anteriorly with 13-14; III, 19-21 (2); IV, 17-20 (15); V, 21-26 (13-16); VI, 16-21 (13-16); VII, 5 (9-15); VIII-IX, 32-37; vulvar margin with 10-11 setae. Each pleurite III-VII with about 5-8 short marginal setae; presence of 1 anterior setae rarely on pleurites III-V; pleurite VIII as in Fig. 15. Tergite IX with inner posterior setae set near lateral margin of last tergite, 0.03-0.04 long (Fig. 13). Anus with 36-39 ventral fringe setae, 34-37 dorsal. Dimensions $(n=3)$ : TW, 0.39-0.42; POW, 0.31-0.32; HL, 0.28-0.29; PW, 0.26; PSPL, 0.11; MW, 0.35-0.37; MSPL, 0.18; AWIV, 0.48-0.52; ANW, 0.19-0.20; TL, 1.39-1.43.

Male. Much as in female, habitus as in Fig. 4. Gular plate with 4 setae on each side. Metanotum with 4 setae on posterior margin. Setae of femoral brush, 11-13. Tergal setae: I, 7-8; II, 8-9; III, 9; IV, 7-8; V, 7-8; VI, 6-8; VII, 5-6; VIII, 4. Median gap present in each tergal setal row; tergal setae of similar length reaching alveoli of next tergal row. Postspiracular setae as for female. Pattern of chaetotaxy of tergites V-IX $+\mathrm{X}$ as in Fig. 22.

Anterior row of setae present on sternites. Sternal setae: I, 0; II, each aster of 5 setae (rarely 4 only in one side), posterior margin with 9-12 and anteriorly with 9-12; III, 17-20 (0-1); IV, 23-26 (2-6); V, 20-22 (11); VI, 19 (10-12); VII, 13-17 (6-7); VIII, 21-23. Tergite IX with inner posterior setae set near lateral margin of last tergite, 0.02-0.03 long (Fig. 22). Anus with 6 internal setae on ventral side and 3 on dorsal. Genital sac sclerite as in Fig. 19. Dimensions $(\mathrm{n}=3)$ : TW, 0.37-0.38; POW, 0.29-0.30; HL, 0.25-0.26; PW, 0.24-0.25; PSPL, 0.09-0.10; MW, 0.31-0.32; MSPL, 0.16; AWIV, 0.39-0.40; GL, 0.30-0.33; GSL, 0.06; TL, 1.11-1.15.

Type host: Formicarius colma Boddaert - rufous-capped antthrush (Formicariidae).

Ty p e 1 o c a li ty: Rio Acanauí, Japurá, Amazonas State, Brazil (0201'38"S; 66040'28"W).

Type materia 1: Holotype female (MZUSP 2314), ex Formicarius colma, JAP385 MPEG 62957; Rio Acanauí, Município Japurá, Amazonas State, Brazil, 20 July 2007, collected by J.D. Weckstein. Paratypes: three males and two females, same data as the holotype. Coll. Nos.: one male (FMNH-INS 94002) and one female (FMNH-INS 94003, DNA voucher Mysp.Foco.1.4.2011.3); two males (MZUSP 2316, 2317) and one female (MZUSP 2315).

Etymology: Composed by circum- (= around in Latin); -stern (= the breast, breastbone in Greek), which refers the fact that this species possesses sternal plate I almost surrounded by segment II.

Diagnosis. Morphologically close to M. klimesi and $M$. isacantha sp. n. by sharing the above-mentioned characters for species parasitic on Formicariidae. However, $M$. circumsternata sp. n. has sparser chaetotaxy (including metanotal, metaesternal, femoral brush, tergal and sternal setae), and only three outer latero-ventral setae, in both sexes; the absence of anterior row of setae on male tergites of $M$. circumsternata promptly distinguishes it from its genetically close relative ( $M$. isacantha $\mathrm{sp}$. n. see above). On the other hand, these features make $M$. circumsternata morphologically close to M. klimesi, from which it can be easily distinguished based on chaetotaxy of sternite II, the smaller number of posterior setae and 
the larger number of anterior setae that separate both sexes of these species (see key below).

\section{Key for the Myrsidea species parasitic on Formicariidae}

1 First tibia with 3 outer ventrolateral setae; both sexes with a median gap in each tergal setal row on segments I-III; anterior setae on sternite II, less than 15 setae; aster of sternite II with spine-like setae of distinct length; reminiscent aster on sternites III present

- First tibia with 4 outer ventrolateral setae; both sexes without a median gap, with a continuous tergal setal row on segments I-III; anterior setae on sternite II, more than 15 setae; aster of sternite II with spine-like setae of same length; reminiscent aster on sternites III absent M. isacantha sp. $\mathrm{n}$.

2 Setae on sternite II: posterior margin with 18-23 and anteriorly with 4-7; reminescent aster on sternites III very conspicuous M. klimesi Sychra, 2006

- Setae on sternite II: posterior margin with 9-13; anteriorly with 9-14; reminescent aster on sternites III weak and discrete M. circumsternata sp. $\mathrm{n}$.

\section{Species from Thraupidae}

Major reviews: Price and Dalgleish (2006), Price and Johnson (2009), Sychra et al. (2009), Kounek et al. (2011a).

\section{Myrsidea cacioppoi $\mathrm{sp} . \mathrm{n}$.}

Figs. 5, 6, 23-27

Female. Habitus and head shape as in Fig. 5. Dorsal head seta 10, 0.033-0.047 long; dhs11, 0.092-0.114 long, ratio dhs10/11 0.289-0.489. Hypopharynx fully developed, $l s 50.06-0.07$, ventrolateral fringe, $9-10$ setae. Gula with 4 setae on each side. First tibia with 3 and 4 outer lateral ventral and dorsal setae, respectively. Mesonotum without median division. Metanotum with posterior margin straight and 4 setae on posterior margin, metasternal plate with 4 setae (as in Fig. 25). Setae of femoral brush, 13-17. Metanotum and abdomen as in Fig. 23. Tergites I-II with straight posterior margin, segments III-IV very slightly pronounced on posterior margin. With a median gap in each tergal setal row. Tergal setae: I, 4-8; II, 11-12; III, 11-12; IV, 12-14; V, 12-15; VI, 10-14; VII, 10-12; VIII, 6-7. Postspiracular setae shortest $(0.19-0.22)$ on I, III, V and VI, and extremely long (0.26-0.55) on II, IV, VII and VIII.

Sternal setae: I, 0; II, each aster of 4 setae (one paratype with 3 only on one side), posterior margin with 13-14 and anteriorly with 4-6; III, 21-23; IV, 31-35; V, 37-38; VI, 32-37; VII, 16-19; VIII-IX, 7-8; vulvar margin with 11 setae. Each pleurite III-VII with about 5-8 short marginal setae; absence of anterior setae on pleurites; pleurite VIII as in Fig. 24. Tergite IX with 1 inner posterior setae, on each side, 0.07-0.08 long. Anus with 33-37 ven- tral fringe setae, 34-35 dorsal. Dimensions $(n=3)$ : TW, 0.49-0.51; POW, 0.36-0.37; HL, 0.35; PW, 0.30-0.31; PSPL, 0.12-0.13; MW, 0.47-0.49; MSPL, 0.16-0.17; AWIV, 0.65-0.67; ANW, 0.21-0.23; TL, 1.60-1.64.

Male. Much as in female, habitus as in Fig. 6. Gular plate with 4 setae on each side. Metanotum with 4 setae on posterior margin. Setae of femoral brush, 12-15. Tergal setae: I, 4-8; II, 7-11; III, 9-11; IV, 9-12; V, 9-12; VI, 9-10; VII, 6-9; VIII, 4-5. Without median gap in each tergal setal row; tergal setae of similar length reaching the alveoli of the next tergal row. Postspiracular setae as for female. Pattern of chaetotaxy of tergites $\mathrm{V}-\mathrm{IX}+\mathrm{X}$ as in Fig. 26.

Sternal setae: I, 0; II, each aster of 4 setae, posterior margin with 13-15 and anteriorly with 5; III, 18-22; IV, 27; V, 31-34; VI, 24-29; VII, 13-17; VIII, 10-12. Tergite IX with 1 inner posterior setae, on each side, 0.06-0.08 long. Anus with 8 internal setae on ventral side and 3 on dorsal. Genital sac sclerite as in Fig. 27, rounded apically and with ventral arms laterally projected and curved. Dimensions $(n=3)$ : TW, 0.45-0.46; POW, 0.34; HL, 0.31-0.33; PW, 0.28-0.31; PSPL, 0.11-0.12; MW, 0.40-0.41; MSPL, 0.14-0.15; AWIV, 0.49-0.52; GL, 0.43-0.48; GSL, 0.06-0.10; TL, 1.33-1.40.

Ty pe host: Lanio fulvus (Boddaert) - fulvous shrike-tanager (Thraupidae).

Type locality: Lago Cumapi, Município Maraã, Amazonas State, Brazil (01'33'35"S; 6552'48"W).

Type material: Holotype female (MZUSP 2318), ex Lanio fulvus, JAP780 MPEG 63215; Lago Cumapi, Município Maraã, Amazonas State, Brazil, 31 July 2007, collected by J.D. Weckstein. Paratypes: three males and two females, same data as the holotype. Coll. Nos.: one male (FMNHINS 94004, DNA voucher Mysp.Lafu.1.4.2011.7) and one female (FMNH-INS 94005) paratypes at FMNH; two males (MZUSP 2320, 2321) and one female (MZUSP 2319).

E ty m o log y: This species is named in honour of Joseph Cacioppo, who has sequenced DNA from more Myrsidea than any other person alive and whose senior thesis project produced the largest phylogeny (unpublished data) yet of this megadiverse louse genus.

Diagnosis. Belonging to the fusca species group (sensu Price and Dalgleish 2006), based on the presence of a median gap in the rows of tergal setae in both sexes. Morphologically close to M. spizae Price et Dalgleish, 2006 based on unmodified tergites I-III and the smaller number of metanotal and metasternal setae. Both sexes can be promptly distinguished by their large dimensions (TL of female, 1.60-1.64 vs 1.47-1.56; male, 1.33-1.40 vs 1.22-1.25).

Females of $M$. cacioppoi sp. n. can be separated from those of $M$. spizae based on large number of setae on: tergites VI (10-14 vs 6-7, the 10-11 of Price and Dalgleish 2006) and sternite VI (32-37 vs 22-24). The males can also be separated based on large number of setae on: tergite VI (9-10 setae vs 6 of Price and Dalgleish 2006), 

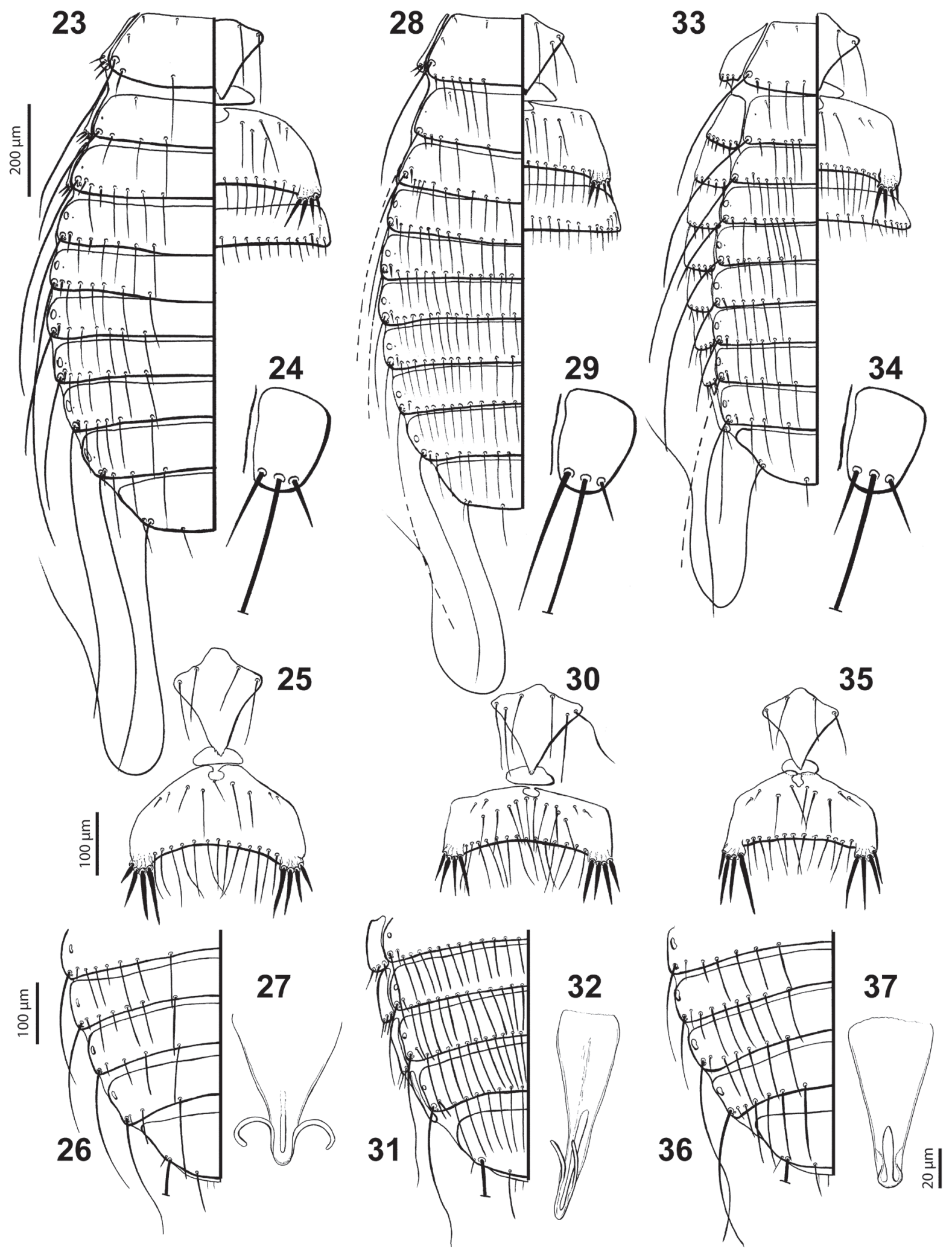

Figs. 23-27. Myrsidea cacioppoi sp. n. Figs. 28-32. M. brasiliensis sp. n. Figs. 33-37. M. saviti sp. n. Female metanotum and dorsal abdomen $(23,28,33)$. Pleurite VIII of female $(24,29,34)$. Metasternal, sternal I and II plates $(25,30,35)$. Tergites V-IX + X of male $(26,31,36)$. Male genital sclerite $(27,32,37)$. 
and sternite VI (24-29 vs 19-20). Males of the new species are distinct from other Myrsidea parasitic on Thraupidae by the shape of the genital sclerite (Fig. 27).

\section{Myrsidea brasiliensis sp. $\mathrm{n}$.}

Figs. 7, 8, 28-32

Female. Habitus and head shape as in Fig. 7. Dorsal head seta 10, 0.034 long; dhs11, 0.095 long, ratio dhs 10/11 0.358. Hypopharynx fully developed, ls 50.07 , ventrolateral fringe, 10 setae. Gula with 5 setae on each side. First tibia with 3 and 4 outer lateral ventral and dorsal setae, respectively. Mesonotum without median division. Metanotum with posterior margin straight and 12 setae on posterior margin, metasternal plate with 6 setae (as in Fig. 30). Setae of femoral brush, 18. Metanotum and abdomen as in Fig. 28. Tergites I-III roughly straight on posterior margin, those of II-III with a very indistinct posterior enlargement. Median gap present in each tergal setal row, most noticeably on segments I-III and VIII. Segments IV-VII with a continuous row of setae. Tergal setae: I, 10; II, 19; III, 21; IV, 27; V, 26; VI, 22; VII, 22; VIII, 14. Postspiracular setae shortest (0.12-0.19) on I, III, $\mathrm{V}$ and VI, and long $(\sim 0.43)$ on II, IV, VII and VIII.

Sternal setae: I, 0; II, each aster of 4 setae, posterior margin with 16 and anteriorly with 9; III, 30; IV, 39; V, 41; VI, 37; VII, 21; VIII-IX, 9; vulvar margin with 12 setae. Each pleurite III-VII with about 4-8 short marginal setae, three first medial setae on ventral surface distinctly longer and setiform on III-VII; absence of anterior setae on pleurites; pleurite VIII as in Fig. 29. Tergite IX with 1 inner posterior setae, on each side, 0.09 long. Anus with 34 ventral fringe setae, 35 dorsal. Dimensions $(n=1)$ : TW, 0.44; POW, 0.34; HL, 0.30; PW, 0.29; PSPL, 0.11; MW, 0.44; MSPL, 0.17; AWIV, 0.58; ANW, 0.21; TL, 1.55.

Male. Much as in female, habitus as in Fig. 8. Gular plate with 5 setae on each side. Metanotum with 10-12 setae on posterior margin. Setae of femoral brush, 18. Tergal setae: I, 17-19; II, 23-24; III, 24-25; IV, 24-26; V, 25-27; VI, 25-26; VII, 24-25; VIII, 17-18. Without median gap in each tergal setal row; tergal setae of similar length reaching alveoli of next tergal row. Postspiracular setae as for female. Pattern of chaetotaxy of tergites V-IX $+\mathrm{X}$ as in Fig. 31.

Sternal setae: I, 0; II, each aster of 4 setae, posterior margin with 14-18 and anteriorly with 10; III, 23-26; IV, 34-35; V, 38-39; VI, 32-33; VII, 22-24; VIII, 18. Tergite IX with 1 inner posterior setae, on each side, 0.08 long. Anus with 8 internal setae on ventral side and 3-4 on dorsal. Genital sac sclerite as in Fig. 32, rounded apically and with thin and long ventral arms. Dimensions $(\mathrm{n}=2)$ : TW, 0.40-0.41; POW, 0.31; HL, 0.30; PW, 0.27; PSPL, 0.11; MW, 0.35-0.36; MSPL, 0.14; AWIV, 0.45; GL, 0.40-0.44; GSL, 0.10-0.11; TL, 1.22-1.27.

Type host: Tangara chilensis (Vigors) - paradise tanager (Thraupidae)

Type locality: Rio Mapari, Município Japurá, Amazonas
State, Brazil $\left(02^{\circ} 02^{\prime} 32^{\prime \prime} \mathrm{S} ; 67^{\circ} 17^{\prime} 17^{\prime \prime} \mathrm{W}\right)$.

Type material: Holotype female (MZUSP 2322, DNA voucher Mysp.Tach.1.4.2011.8), ex Tangara chilensis, JAP010 MPEG 63218; Rio Mapari, Município Japurá, Amazonas State, Brazil, 10 July 2007, collected by J.D. Weckstein. Paratypes: two males, same data as the holotype. Coll. Nos.: one male (FMNH-INS 94006); one male (MZUSP 2323).

Ety mology: Specific name is derived from country of origin (Brasilia).

Diagnosis. Belonging to the bonariensis species group (sensu Price and Dalgleish 2006), based on the presence, in both sexes, of a continuous row of setae on most tergites. Morphologically close to females of $M$. icterocephalae Price et Dalgleish, 2006 by tergite I lacking an extensive median enlargement; tergite I with $<15$ setae; tergites III-V with $>20$ setae; tergite VIII with $<18$ setae; postspiracular setae IV long (similar to length of II or VIII). Males also morphologically close to $M$. icterocephalae by the normal-sized (not enlarged) metanotum and with $>6$ marginal setae (8 of Price and Dalgleish 2006); tergite I with $>14$ and $<22$ setae (16-24 of Price and Dalgleish 2006); tergite III with $>20$ setae ( 24 of Price and Dalgleish 2006); tergite IV-VI with $>15$ and $<25$ setae (19-29 of Price and Dalgleish 2006); and tergite VIII with 13-14 setae (17-18 of Price and Dalgleish 2006).

Both sexes can be promptly identified by the chaetotaxy on tergites VIII (females, 14 vs 15-20 in M. icterocephalae; and males, 17-18 vs 3-7 in M. icterocephalae), and the tergal modifications in females of the new species are more discreet when compared with $M$. icterocephalae. Another possible distinctive character is the long length of the inner setae of the pleurite VIII in M. brasiliensis sp. n., which is at least 3 times longer than the outer setae on pleurite VIII. Whether one would group the new species with $M$. violaceae Price et Dalgleish, 2006, would depend on the individual examined from our type series (see, e.g. couplet 7 for females and 10 for males of the key presented by Price and Dalgleish 2006). However, they can be separated based on the slightly more numerous setae on sternites IV-VI and by the shape of the male genital sclerites.

\section{Myrsidea saviti sp. n.}

Figs. 9, 10, 33-37

Female. Habitus and head shape as in Fig. 9. Dorsal head seta 10, 0.037 long; dhs11, 0.095-0.101 long, ratio dhs 10/11 0.366-0.389. Hypopharynx fully developed, ls5 0.06-0.07, ventrolateral fringe, 10 setae. Gula with 4 setae on each side. First tibia with 3 and 4 outer lateral ventral and dorsal setae, respectively. Mesonotum without median division. Metanotum with posterior margin straight and 8 setae on posterior margin, metasternal plate with 5-6 setae (as in Fig. 35). Setae of femoral brush, 14. Metanotum and abdomen as in Fig. 33. Tergites I-III very slightly pronounced on posterior margin. Median gap 
present in each tergal setal row. Tergal setae: I, 11-12; II, 15; III, 14; IV, 12-13; V, 13; VI, 10-12; VII, 9-11; VIII, 6-8. Postspiracular setae shortest $(0.12-0.14)$ on III, $\mathrm{V}$ and VI, and long $(0.20-0.49)$ on I, II, IV, VII and VIII.

Sternal setae: I, 0; II, each aster of 4 setae, posterior margin with 17 and anteriorly with 4-5; III, 22-23; IV, 30-33; V, 32-38; VI, 32; VII,19; VIII-IX, 10-11; vulvar margin with 10-11 setae. Each pleurite III-VII with about 5-8 short marginal setae; absence of anterior setae on pleurites; pleurite VIII as in Fig. 34. Tergite IX with 1 inner posterior seta, on each side, 0.07 long. Anus with 32 ventral fringe setae, 30-32 dorsal. Dimensions (n=2): TW, 0.43-0.44; POW, 0.32-0.33; HL, 0.31; PW, 0.28; PSPL, 0.11; MW, 0.41; MSPL, 0.14-0.15; AWIV, 0.53-0.55; ANW, 0.20-0.21; TL, 1.42-1.43.

Male. Much as in female, habitus as in Fig. 10. Gula with 4 setae on each side (one paratype with 5 on only one side). Metanotum with 8 setae on posterior margin. Setae of femoral brush, 11-14. Tergal setae: I, 7-10; II, 10-11; III, 10-13; IV, 10; V, 10-12; VI, 11-14; VII, 8-10; VIII, 9-10. Median gap present in each tergal setal row; tergal setae of similar length reaching the alveoli of the next tergal row. Postspiracular setae as for female. Pattern of chaetotaxy of tergites V-IX $+\mathrm{X}$ as in Fig. 36.

Sternal setae: I, 0; II, each aster of 4 setae (one paratype with 5 in only one side), posterior margin with 13-17 and anteriorly with 4-5; III, 17-20; IV, 21-25; V, 25-28; VI, 22-25; VII, 12-13; VIII, 12-15. Tergite IX with 1 inner posterior setae, on each side, 0.06-0.07 long. Anus with 8 internal setae on ventral side and 3 on dorsal. Genital sac sclerite as in Fig. 37, rounded apically and without distinct lateral arms. Dimensions $(\mathrm{n}=3)$ : TW, 0.39; POW, 0.29; HL, 0.27-0.28; PW, 0.25-0.26; PSPL, 0.10; MW, 0.33-0.34; MSPL, 0.12-0.13; AWIV, 0.40-0.41; GL, 0.38-0.39; GSL, 0.08-0.09; TL, 1.13-1.16.

Type host: Tangara schrankii (Spix) - green-and-gold tanager (Thraupidae).

Type lo c a lity: Rio Acanaú, Município Japurá, Amazonas State, Brazil $\left(02^{\circ} 01^{\prime} 38^{\prime \prime S}\right.$; 66 $\left.46^{\circ} 28^{\prime \prime} \mathrm{W}\right)$.

Type materia 1: Holotype female (MZUSP 2324), ex Tangara schrankii, JAP378 MPEG 63222; Rio Acanauí, Município Japurá, Amazonas State, Brazil, 20 July 2007, collected by J.D. Weckstein. Paratypes: three males and one female, same data as the holotype. Coll. Nos.: one male (FMNH-INS 94007) and one female (FMNH-INS 94008, DNA voucher Mysp.Tasch.1.4.2011.9); two males (MZUSP 2325, 2326).

Ety mology: Named in honour of Aaron Zvi Savit for his love of Thraupidae, Tangara in particular, and for collecting so many Thraupidae Myrsidea and other avian ecto- and endoparasites.

Diagnosis. Belonging to the fusca species group (sensu Price and Dalgleish 2006), based on the above-mentioned characters. Morphologically similar to M. spizae by lack of modifications on tergites I-III, and by fewer metasternal plate setae (only two pairs). However, fe- males of M. saviti sp. n. have more setae on metanotal, tergal (e.g. VI, 10-12 vs 6-7) and sternal plates (e.g. VI, 32 vs 22-24); for the males, the shapes of the male genital sclerites are conspicuously distinct between these two species.

\section{Species from Tyrannidae}

Major review: Price et al. (2005).

Myrsidea cinnamomei Dalgleish et Price, 2005

Myrsidea cinnamomei Dalgleish et Price, 2005: 2, Type host and locality. Pachyramphus cinnamomeus Lawrence from Costa Rica. Valim et al., 2011: 13, ex P. homochrous Sclater in Panama.

Hosts: Pachyramphus cinnamomeus - Dalgleish and Price (2005), P. homochrous - Valim et al. (2011) (both Tityridae); Attila citriniventris Sclater - present study (Tyrannidae).

Material examined: three males and three females, ex Attila citriniventris, JAP141 MPEG 63079; Rio Mapari, Município Japurá, Amazonas State, Brazil $\left(02^{\circ} 02^{\prime} 32^{\prime \prime}\right.$; $67^{\circ} 17^{\prime} 17^{\prime \prime}$ ), 13 July 2007 , collected by J.D. Weckstein. Coll. Nos.: one male (FMNH-INS 94009) and one female (FMNH-INS 94010, DNA voucher Mysp.Atci.1.4.2011.11); two males (MZUSP 2329, 2330) and two females (MZUSP 2327, 2328) .

Remarks. This Myrsidea species is unusual in several ways. First, $M$. cinnamomeus is now known to parasitise three host species, Pachyramphus cinnamomeus, P. homochrous and Attila citriniventris. The specimens from these three hosts are morphologically indistinguishable and DNA sequence data for $M$. cinnamomei from two of these hosts, $P$. homochrous and $A$. citriniventris, confirm that these parasites are in fact nearly identical (uncorrected mtDNA sequence divergence $=0.79 \%$ ) as well.

Second, this louse species is found on two genera of hosts including Attila, which is in the family Tyrannidae, and Pachyramphus, which has been associated with the avian suboscine families Tyrannidae, Cotingidae and Tityridae (suborder Tyranni). Most recent molecular analyses place Pachyramphus in the avian family Tityridae (Ohlson et al. 2007a,b), which is related to Tyrannidae. However, the two avian genera that host M. cinnamomei, Pachyramphus and Attila, are not particularly closely related within the suboscine passerine tree of life.

Third, not only is M. cinnamomei found on multiple host species and genera, but it is also found in both Central America and South America and thus has a crossAndes distribution. We only know of a handful of other records of Myrsidea species with cross-Andes distributions, M. seminuda ex Thraupis palmarum and T. episcopus in Costa Rica (Price and Dalgleish 2006) and ex T. palmarum in Brazil (Sychra et al. 2009). Additional genetic data from these and other cross-Andes louse taxa will help clarify whether there is ongoing geneflow or recent separation of populations of chewing lice in these cross-Andes regions. 


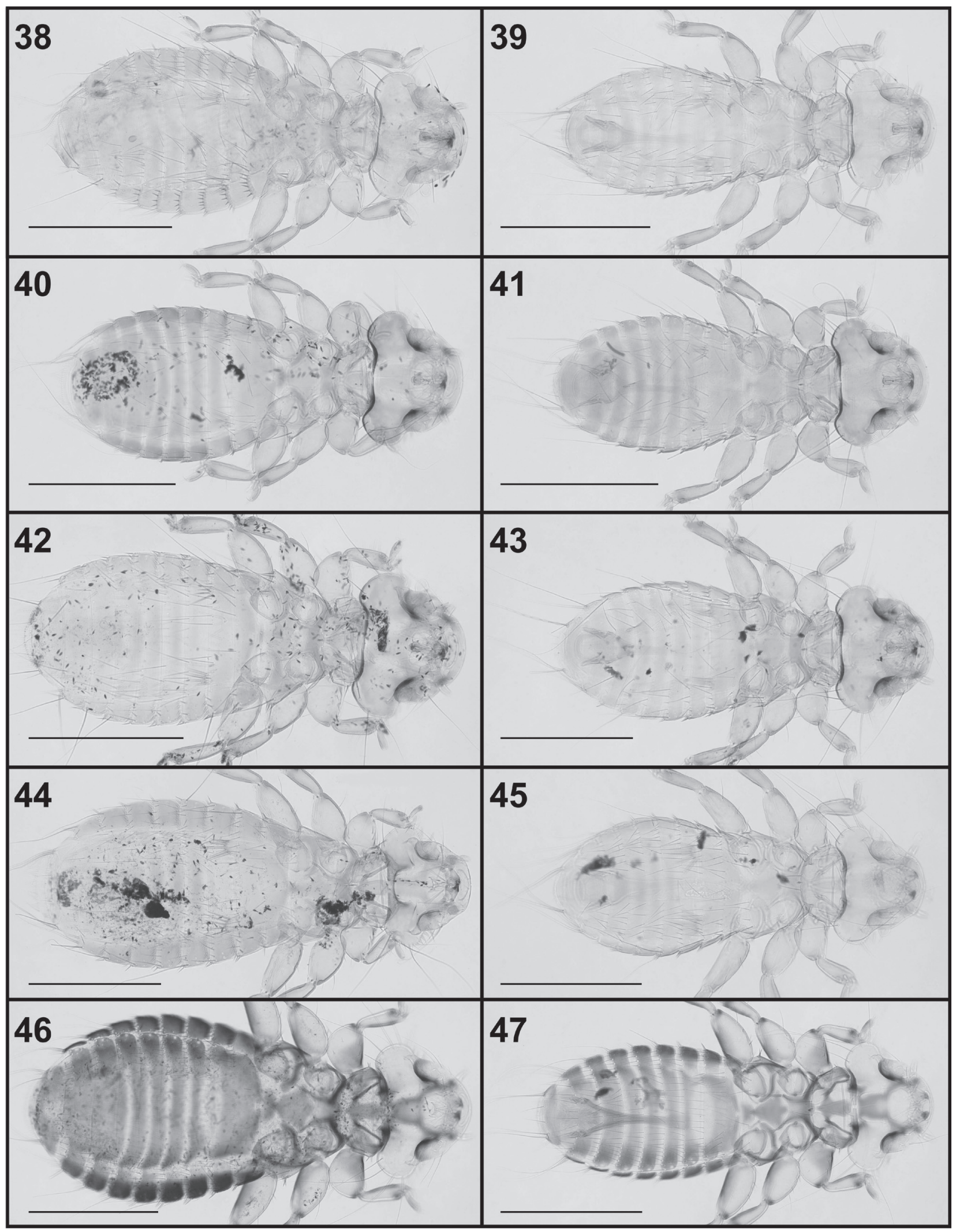

Figs. 38-47. Habitus in dorsal view. Females in left column, males in right column. Figs. 38, 39. Myrsidea rodriguesae sp. n. Figs. 40, 41. . cnemotriccola sp. n. Figs. 42, 43. M. lathrotriccola sp. n. Figs. 44, 45, M. faccioae sp. n. Figs. 46, 47. M. lampropsaricola $\mathrm{sp} . \mathrm{n}$. Scale bars $=0.5 \mathrm{~mm}$. 


\section{Myrsidea rodriguesae $\mathrm{sp} . \mathrm{n}$.}

Figs. 38, 39, 48-52

Female. Habitus and head shape as in Fig. 38. Dorsal head seta 10, 0.040-0.057 long; dhs11, 0.088-0.103 long, ratio $d h s 10 / 110.449-0.580$. Hypopharynx fully developed, $l s 50.05-0.06$, ventrolateral fringe, 9 setae. Gula with 4 setae on each side. First tibia with 3 and 4 outer lateral ventral and dorsal setae, respectively. Mesonotum without median division. Metanotum enlarged, with posterior margin conspicuously concave and 4 setae on posterior margin, metasternal plate with 6-7 setae (as in Fig. 50). Setae of femoral brush, 12-13. Metanotum and abdomen as in Fig. 48. Tergites I-III slightly pronounced on posterior margin. Median gap present in each tergal setal row. Tergal setae: I, 11-13; II, 12-16; III, 14-17; IV, 16-17; V, 17-20; VI, 16-20; VII, 13-15; VIII, 5. Postspiracular setae shortest $(0.12-0.24)$ on III, V and VI, and long (0.30-0.52) on I, II, IV, VII and VIII.

Sternal setae: I, 0; II, each aster of 4 setae (one paratype with 2 setae only on one side), posterior margin with 16-20 and anteriorly with 4; III, 26-32; IV, 28-31; V, 30-34; VI, 23-32; VII, 15-20; VIII-IX, 9-15; vulvar margin with 12 setae. Each pleurite III-VII with about 5-10 marginal setae, two first medial on ventral surface distinctly longer and setiform on IV-VII; presence of 1-6 anterior setae on pleurites II-VII; pleurite VIII as in Fig. 49. Tergite IX with 1 inner posterior setae, on each side, 0.05-0.06 long (holotype missing inner posterior setae in both sides). Anus with 37-41 ventral fringe setae, 35-41 dorsal. Presence of 5-6 setae on ventral fringe set submarginal on each side (included in total count). Dimensions $(\mathrm{n}=3)$ : TW, 0.43-0.44; POW, 0.33-0.34; HL, 0.29-0.31; PW, 0.26-0.28; PSPL, 0.10-0.11; MW, 0.40; MSPL, 0.14-0.15; AWIV, 0.57-0.59; ANW, 0.20-0.21; TL, 1.44-1.50.

Male. Much as in female, habitus as in Fig. 39. Gula with 4 setae on each side (rarely 5 setae on one side). Metanotum with 4 setae on posterior margin. Setae of femoral brush, 12-13. Tergal setae: I, 6; II, 8-10; III, 8-10; IV, 11-12; V, 10; VI, 10-12; VII, 6-10; VIII, 4. Median gap present in each tergal setal row. Postspiracular setae as for female. Pattern of chaetotaxy of tergites V-IX $+\mathrm{X}$ as in Fig. 51 .

Sternal setae: I, 0; II, each aster of 4 setae, posterior margin with 14-15 and anteriorly with 3-4; III, 20-24; IV, 21-24; V, 25; VI, 24-26; VII, 14-15; VIII, 10-13. Tergite IX with 1 inner posterior setae (sometimes lacking on one side), on each side, 0.04-0.05 long. Anus with 7-8 internal setae on ventral side and $2-3$ on dorsal. Genital sac sclerite as in Fig. 52, incised apically and with thin subapical lateral projections (lateral arms). Dimensions $(\mathrm{n}=3)$ : TW, 0.40; POW, 0.30-0.32; HL, 0.29; PW, 0.25-0.26; PSPL, 0.10-0.11; MW, 0.35-0.36; MSPL, 0.13-0.14; AWIV, 0.43-0.44; GL, 0.40-0.41; GSL, 0.08-0.09; TL, $1.24-1.27$.
Type host: Cnipodectes subbrunneus (Sclater) - brownish flycatcher (Tyrannidae).

Type locality: Lago Cumapi, Município Maraã, Amazonas State, Brazil (01³3'00"S; 6550'14"W).

Type material: Holotype female (MZUSP 2331), ex Cnipodectes subbrunneus, JAP632 MPEG 63037; Lago Cumapi, Município Maraã, Amazonas State, Brazil, 29 July 2007, collected by J.D. Weckstein. Paratypes: three males and two females, same data as the holotype. Coll. Nos.: one male (FMNH-INS 94011) and one female (FMNH-INS 94012, DNA voucher Mysp.Cnsb.1.4.2011.13); two males (MZUSP 2333, 2334) and one female (MZUSP 2332).

Etymology: This species is named in honour of Elinete Batista Rodrigues in appreciation of her hard work and dedication as a team member that helped make the collection of these louse specimens possible on the joint Museu Paraense Emilío Goeldi/Field Museum of Natural History Japurá expedition.

Diagnosis. Belonging to the pitangi species group (sensu Price et al. 2005), based on the reduced number of abdominal tergal and sternal setae, and by females lacking highly modified anterior tergites. Morphologically close to M. flaviventris Price, Hellenthal et Dalgleish, 2005, male differs in the shape of the genital sclerite (close to that of M. flaviventris, but with posterior portion of the sclerite incised); female differs by the straight shape of the posterior margin of the tergites II-IV (slightly enlarged in I-III of $M$. flaviventris).

The enlargement and sparce chaetotaxy of the metanotum in females are unique features among the Myrsidea species parasitizing Tyrannidae. The only species with some metanotal enlargement are $M$. olivacei Price, Hellenthal et Dalgleish, 2005 and M. spadicei Price, Hellenthal et Dalgleish, 2005, but they can be promptly distinguished in both sexes by fewer metanotal setae in M. rodriguesae sp. n. (4 vs 8-11, 10-13, respectively, of Price et al. 2005). On the other hand, the only Myrsidea species parasitizing Tyrannidae with such sparse metanotal chaetotaxy is M. barbati Price, Hellenthal et Dalgleish, 2005, which differs from $M$. rodriguesae sp. n. by the shape of the metanotum (not enlarged in M. barbati), larger number of tergal setae and shape of genital sclerite in males.

\section{Myrsidea cnemotriccola sp. $\mathrm{n} . \quad$ Figs. 40, 41, 53-57}

Female. Habitus and head shape as in Fig. 40. Dorsal head seta 10, 0.051-0.054 long; dhs11, 0.103-0.115 long, ratio dhs 10/11 0.443-0.524. Hypopharynx fully developed, ls 5 0.04-0.05, ventrolateral fringe, 10. Gula with 5 setae on each side. First tibia with 3 and 4 outer lateral ventral and dorsal setae, respectively. Mesonotum without median division. Metanotum with posterior margin straight and 8 setae on posterior margin, metasternal plate with 6 setae (as in Fig. 55). Setae of femoral brush, 13. Metanotum and abdomen as in Fig. 53. Tergites I-III very 


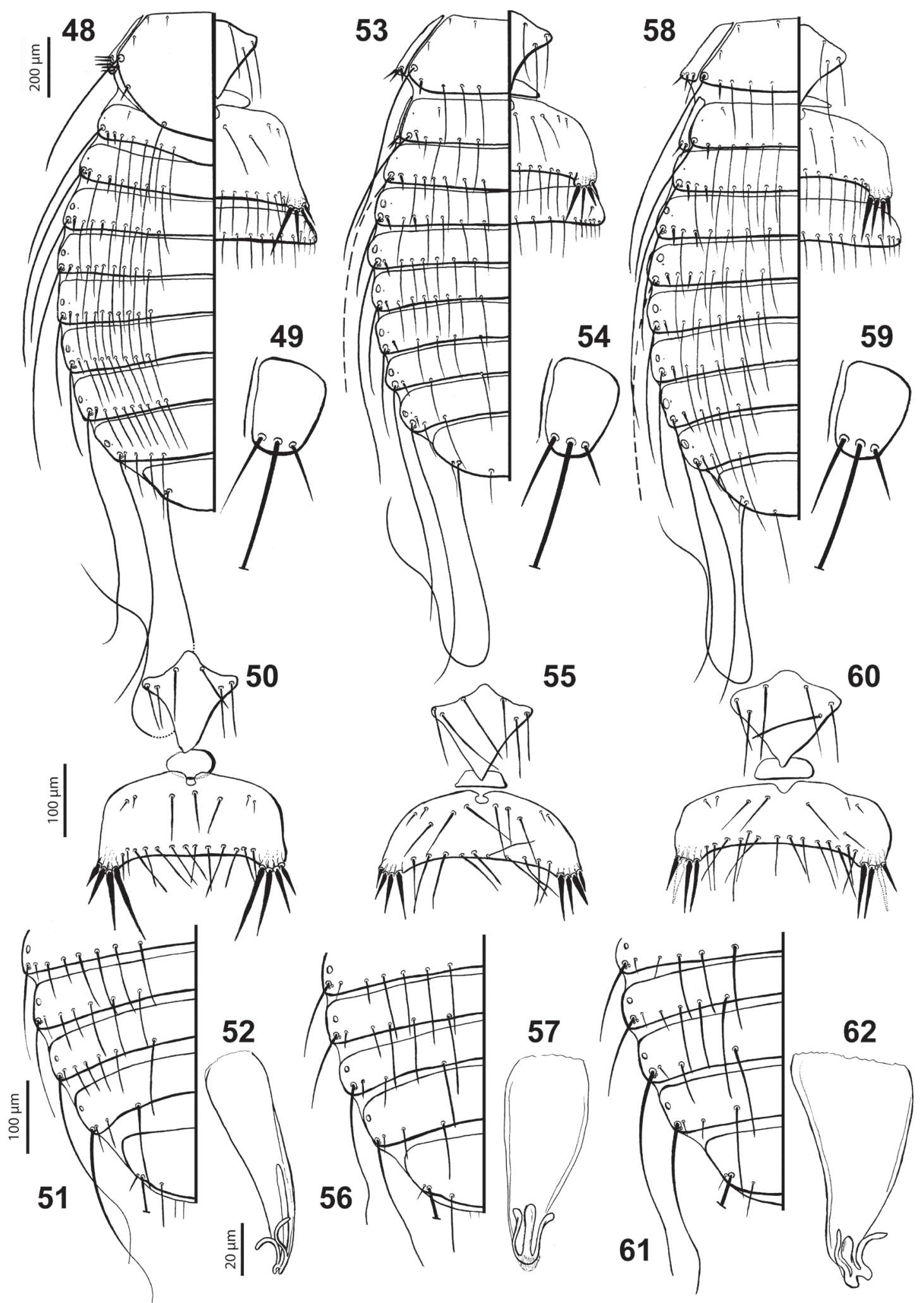

Figs. 48-52. Myrsidea rodriguesae sp. n. Figs. 53-57. M. cnemotriccola sp. n. Figs. 58-62. M. lathrotriccola sp. n. Female metanotum and dorsal abdomen $(48,53,58)$. Pleurite VIII of female $(49,54,59)$. Metasternal, sternal I and II plates $(50,55,60)$. Tergites $\mathrm{V}-\mathrm{IX}+\mathrm{X}$ of male $(51,56,61)$. Male genital sclerite $(52,57,62)$. 
slightly posterior pronounced, but undoubtedly of similar size. Median gap present in each tergal setal row. Tergal setae: I, 11; II, 12; III, 11; IV, 11; V, 12; VI, 8; VII, 4; VIII, 4. Postspiracular setae shortest $(0.15-0.21)$ on III, V and VI, and long (0.26-0.44) on I, II, IV, VII and VIII.

Sternal setae: I, 0; II, each aster of 4 setae, posterior margin with 15 and anteriorly with 6; III, 22; IV, 31; V, 33; VI, 27; VII, 10; VIII-IX, 9; vulvar margin with 12 setae. Each pleurite III-VII with about 5-11 short marginal setae; absence of anterior setae on pleurites; pleurite VIII as in Fig. 54. Tergite IX with 1 inner posterior setae, on each side, $0.06-0.07$ long. Anus with 34 ventral fringe setae, 33 dorsal. Dimensions $(\mathrm{n}=1)$ : TW, 0.45; POW, 0.34; HL, 0.30; PW, 0.26; PSPL, 0.11; MW, 0.41; MSPL, 0.15; AWIV, 0.53; ANW, 0.20; TL, 1.33.

Male. Much as in female, habitus as in Fig. 41. Gula with 5 setae on each side, rarely 4 setae on one side. Metanotum with 5 setae on posterior margin. Setae of femoral brush, 13-15. Tergal setae: I, 5-6; II, 8-9; III, 9-11; IV, 9-10; V, 10-11; VI, 4; VII, 4; VIII, 6. Median gap present in each tergal setal row. Postspiracular setae as for female. Pattern of chaetotaxy of tergites $\mathrm{V}-\mathrm{IX}+\mathrm{X}$ as in Fig. 56.

Sternal setae: I, 0; II, each aster of 4 setae (rarely 3 only on one side), posterior margin with $10-14$ and anteriorly with 5-6; III, 18-19; IV, 24; V, 24-27; VI, 22-23; VII, 10-11; VIII, 8-10. Tergite IX with 1 inner posterior setae, on each side, $0.05-0.07$ long. Anus with 8 internal setae on ventral side, and 3-4 on dorsal. Genital sac sclerite as in Fig. 57, rounded apically and with short and thick subapical lateral projections. Dimensions $(\mathrm{n}=2)$ : TW, 0.41-0.42; POW, 0.31-0.33; HL, 0.28-0.29; PW, 0.25-0.26; PSPL, 0.10; MW, 0.35-0.36; MSPL, 0.12-0.13; AWIV, 0.43-0.44; GL, 0.37-0.39; GSL, 0.08; TL, 1.19-1.20.

Type host: Cnemotriccus fuscatus (Wied-Neuwied) - fuscous flycatcher (Tyrannidae).

Type locality: Rio Mapari, Município Japurá, Amazonas State, Brazil $\left(02^{\circ} 02^{\prime} 60^{\prime \prime} \mathrm{S} ; 67^{\circ} 15^{\prime} 47^{\prime \prime} \mathrm{W}\right)$.

Type material: Holotype female (MZUSP 2335, DNA voucher Mysp.Cnfu.1.4.2011.12), ex Cnemotriccus fuscatus, JAP226 MPEG 63051; Rio Mapari, Município Japurá, Amazonas State, Brazil, 15 July 2007, collected by J.D. Weckstein. Paratypes: two males, same data as the holotype. Coll. Nos.: one male (FMNH-INS 94013); one male (MZUSP 2336).

Etymology: Composed by Cnemotriccus, the monotypic genus of the host; and -cola (= dwell in Latin).

Diagnosis. Belonging to the pitangi species group (sensu Price et al. 2005), based on the reduced number of abdominal tergal and sternal setae, and by females lacking highly modified anterior tergites. The females have a slightly pronounced posterior margin on tergites I-III, making it morphologically close to $M$. lathrotriccola sp. n. (see below). They differ in both sexes by the relatively short tergal setae, reaching at most the alveolus or slightly surpassing it, never reaching the middle of next seta (in M. lathrotriccola these setae reach the middle of the length of the tergal setae on next segment; $t$-test $\mathrm{p}=0.0001, \mathrm{~N}=20$ setae measured). Males of M. cnemotriccola sp. n. have the same type of genital sclerites as $M$. lathrotriccola, with slight differences including rounded posterior margin (incised in M. lathrotriccola), longer median sclerotization, occupying about $1 / 3$ of the entire sclerite (1/5 in M. lathrotriccola) and shorter inner setae on tergite IX (0.05-0.07 vs 0.02 in M. lathrotriccola). Other characters also distinguish these two morphologically similar species. The rough shape of the sternites II are distinctive (compare Figs. 55 and 60). The females are also most distinguishable by the length of inner setae on tergite IX (0.06-0.07 vs 0.14-0.15 in M. lathrotriccola) and by the pattern of chaetotaxy in tergite VII (compare Figs. 53 and 58). In addition to the genetic distinctiviness between these two species (Fig. 73), M. cnemotriccola seems to have the tendency to present smaller body measurements.

Based on the number of setae on sternite $\mathrm{V}(<48)$, posterior margin of metanotum (at least 10, which is our $8+2)$ and temporal width $(<0.48)$, M. cnemotriccola could also be grouped with $M$. contopi Price, Hellenthal et Dalgleish, 2005 and M. elaeniae Price, Hellenthal et Dalgleish, 2005. The females can be distinguished based on slightly pronounced posterior margin of the tergites I-III (more noticeable on M. contopi and M. elaeniae). The males of these species are primarily separated based on the gross shape of their genital sclerites.

\section{Myrsidea lathrotriccola sp. n. $\quad$ Figs. 42, 43, 58-62}

Female. Habitus and head shape as in Fig. 42. Dorsal head seta 10, 0.060 long; dhs11, 0.106 long, ratio $d h s 10 / 110.566$. Hypopharynx fully developed, ls 50.04 , ventrolateral fringe, 10 setae. Gula with 4 setae on each side. First tibia with 3 and 4 outer lateral ventral and dorsal setae, respectively. Mesonotum without median division. Metanotum with posterior margin straight and 8 setae on posterior margin, metasternal plate with 6 setae (as in Fig. 60). Setae of femoral brush, 17. Metanotum and abdomen as in Fig. 58. Tergites unmodified, of similar size. Median gap present in each tergal setal row. Tergal setae: I, 12; II, 12; III, 14; IV, 13; V, 11; VI, 9; VII, 6 VIII, 4. Postspiracular setae shortest $(0.21-0.30)$ on III, V and VI, and extremely long $(0.38-0.56)$ on I, II, VII and VIII. Postspiracular setae IV broken in holotype, but seems to be long.

Sternal setae: I, 0; II, each aster of 4 setae, posterior margin with 14 and anteriorly with 4; III, 21; IV, 37; V, 37; VI, 32; VII, 11; VIII-IX, 11; vulvar margin 9 setae. Each pleurite III-VII with about 4-6 short marginal setae; absence of anterior setae on pleurites; pleurite VIII as in Fig. 59. Tergite IX with 1 inner posterior setae, on each side, 0.14-0.15 long. Anus with 29 ventral fringe setae, 35 dorsal. Dimensions ( $\mathrm{n}=1)$ : TW, 0.47; POW, 0.36; 
HL, 0.33; PW, 0.29; PSPL, 0.10; MW, 0.44; MSPL, 0.13; AWIV, 0.57; ANW, 0.20; TL, 1.44.

Male. Much as in female, habitus as in Fig. 43. Gula with 4 setae on left and 5 setae on right side. Metanotum with 7 setae on posterior margin. Setae of femoral brush, 12. Tergal setae: I, 8; II, 10; III, 10; IV, 11; V, 8; VI, 8; VII, 4; VIII, 3. Median gap present in each tergal setal row. Postspiracular setae as for female. Pattern of chaetotaxy of tergites $\mathrm{V}-\mathrm{IX}+\mathrm{X}$ as in Fig. 61.

Sternal setae: I, 0; II, each aster of 4 setae, posterior margin with 14 and anteriorly with 4; III, 19; IV, 25; V, 30; VI, 27; VII, 11; VIII, 9. Tergite IX with 1 inner posterior setae, on each side, 0.02 long. Anus with 8 internal setae on ventral side, and 4 on dorsal side. Genital sac sclerite as in Fig. 62, notched apically and with well-developed subapical lateral projections. Dimensions $(\mathrm{n}=1)$ : TW, 0.43; POW, 0.34; HL, 0.31; PW, 0.27; PSPL, 0.10; MW, 0.39; MSPL, 0.13; AWIV, 0.47; GL, 0.39; GSL, $0.09 ; \mathrm{TL}, 1.28$.

Type host: Lathrotriccus euleri (Cabanis) - Euler's flycatcher (Tyrannidae).

Type locality: Lago Cumapi, Município Maraã, Amazonas State, Brazil $\left(01^{\circ} 33^{\prime} 35^{\prime \prime} \mathrm{S} ; 65^{\circ} 52^{\prime} 48^{\prime \prime} \mathrm{W}\right)$.

Type material: Holotype female (MZUSP 2337, DNA voucher Mysp.Laeu.1.4.2011.14), ex Lathrotriccus euleri, JAP762 MPEG 63048; Lago Cumapi, Município Maraã, Amazonas State, Brazil, 31 July 2007, collected by J.D. Weckstein. Paratype: one male (MZUSP 2338), same data as the holotype.

Etymology: Composed by Lathrotriccus, the monotypic genus of the host; and -cola (= dwell in Latin).

Diagnosis. Belonging to the pitangi species group (sensu Price et al. 2005), based on the same reasons mentioned above for $M$. cnemotriccola sp. n. and M. rodriguesae sp. n. Morphologically close to M. cnemotriccola by the absence of medioposterior convexity on tergites I-III (slightly developed on II-III in M. cnemotriccola) and by metanotal and tergal chaetotaxy, their main distinctive characters were discussed above (see diagnosis of $M$. cnemotriccola). Also could be grouped with $M$. contopi and M. elaeniae using the same distinctive characters listed above (for M. cnemotriccola). The new species is unique among the Myrsidea parasitizing the Tyrannidae by the complete absence of any medioposterior convexity on tergites I-III in female (see Price et al. 2005).

\section{Species from Troglodytidae}

Major reviews: Price et al. (2008a).

\section{Myrsidea faccioae sp. $\mathrm{n}$.}

Figs. 44, 45, 63-67

Female. Habitus and head shape as in Fig. 44. Dorsal head seta 10, 0.052-0.055 long; dhs11, 0.120-0.125 long, ratio dhs 10/11 0.416-0.458. Hypopharynx reduced, ls 5 0.04 , ventrolateral fringe, 9 setae. Gula with 4 setae on each side. First tibia with 3 and 4 outer lateral ventral and dorsal setae, respectively. Mesonotum without median division. Metanotum with posterior margin straight and 8-9 setae on posterior margin, metasternal plate with 6 setae (as in Fig. 65). Setae of femoral brush, 16. Metanotum and abdomen as in Fig. 63. Tergites I-III straight on posterior margin, without modification. Median gap present in each tergal setal row. Tergal setae: I, 12-13; II, 15-16; III, 16-17; IV, 17; V, 14-16; VI, 12-13; VII, 5-9; VIII, 4. Postspiracular setae shortest $(0.16-0.22)$ on I, III, V and VI, and long (0.34-0.49) on II, IV, VII and VIII.

Sternal setae: I, 0; II, each aster of 6 setae (one paratype with 5 only on one side), posterior margin with 17-20 and anteriorly with 8; III, 21-25; IV, 32-34; V, 38-42; VI, 33-38; VII, 29; VIII-IX, 17-21; vulvar margin spiculated and with 12-13 setae. Each pleurite III-VII with about 5-9 short marginal setae; absence of anterior setae on pleurites; pleurite VIII as in Fig. 64. Tergite IX with 1 inner posterior setae, on each side, 0.04-0.05 long. Anus with 33-39 ventral fringe setae, 39-41 dorsal. Dimensions $(\mathrm{n}=2)$ : TW, 0.45-0.46; POW, 0.34; HL, 0.31; PW, 0.31; PSPL, 0.13; MW, 0.45-0.46; MSPL, 0.16-0.17; AWIV, 0.64; ANW, 0.26; TL, 1.64.

Male. Much as in female, habitus as in Fig. 45. Gular plate with 4 setae on each side (rarely 3 on only one side). Metanotum with 6-8 setae on posterior margin. Setae of femoral brush, 12-13. Tergal setae: I, 10-12; II, 14-15; III, 14-19; IV, 15-18; V, 14-15; VI, 13-16; VII, 10-11; VIII, 6-7. Median gap present in each tergal setal row; tergal setae of similar length reaching the alveoli of the next tergal row. Postspiracular setae as for female. Pattern of chaetotaxy of tergites V-IX + X as in Fig. 66.

Sternal setae: I, 0; II, each aster of 6 setae (one paratype with 7 only on one side), posterior margin with 16-18 and anteriorly with 7-11; III, 16-23; IV, 27-33; V, 33-36; VI, 32-34; VII, 29; VIII, 30-36. Tergite IX with 1 inner posterior setae, on each side, $0.03-0.04$ long. Anus with 8 internal setae on ventral side, and $4-5$ on dorsal. Genital sac sclerite as in Fig. 67. Dimensions $(n=3)$ : TW, 0.41; POW, 0.31; HL, 0.28-0.30; PW, 0.28-0.29; PSPL, 0.10-0.12; MW, 0.39; MSPL, 0.13-0.14; AWIV, 0.500.53; GL, 0.42-0.47; GSL, 0.09; TL, 1.30-1.36.

Ty p e host: Cyphorhinus arada transfluvialis (Todd) - musician wren (Troglodytidae).

Type locality: Lago Cumapi, Município Maraã, Amazonas State, Brazil (0133'35"S; 6552'48"W).

Type material: Holotype female (MZUSP 2339), ex Cyphorhinus arada transfluvialis, JAP713 MPEG 63195; Lago Cumapi, Município Maraã, Amazonas State, Brazil, 30 July 2007, collected by J.D. Weckstein. Paratypes: three males and one female, same data as the holotype. Coll. Nos.: one male (FMNH-INS 94014) and one female (FMNH-INS 94015, DNA voucher Mysp.Cyar.1.4.2011.10); two males (MZUSP 2340, 2341).

Ety mology: This species is named in honour of Maya Sonnenschein Faccio in appreciation of her hard work and dedication as a team member that helped make the collection of 

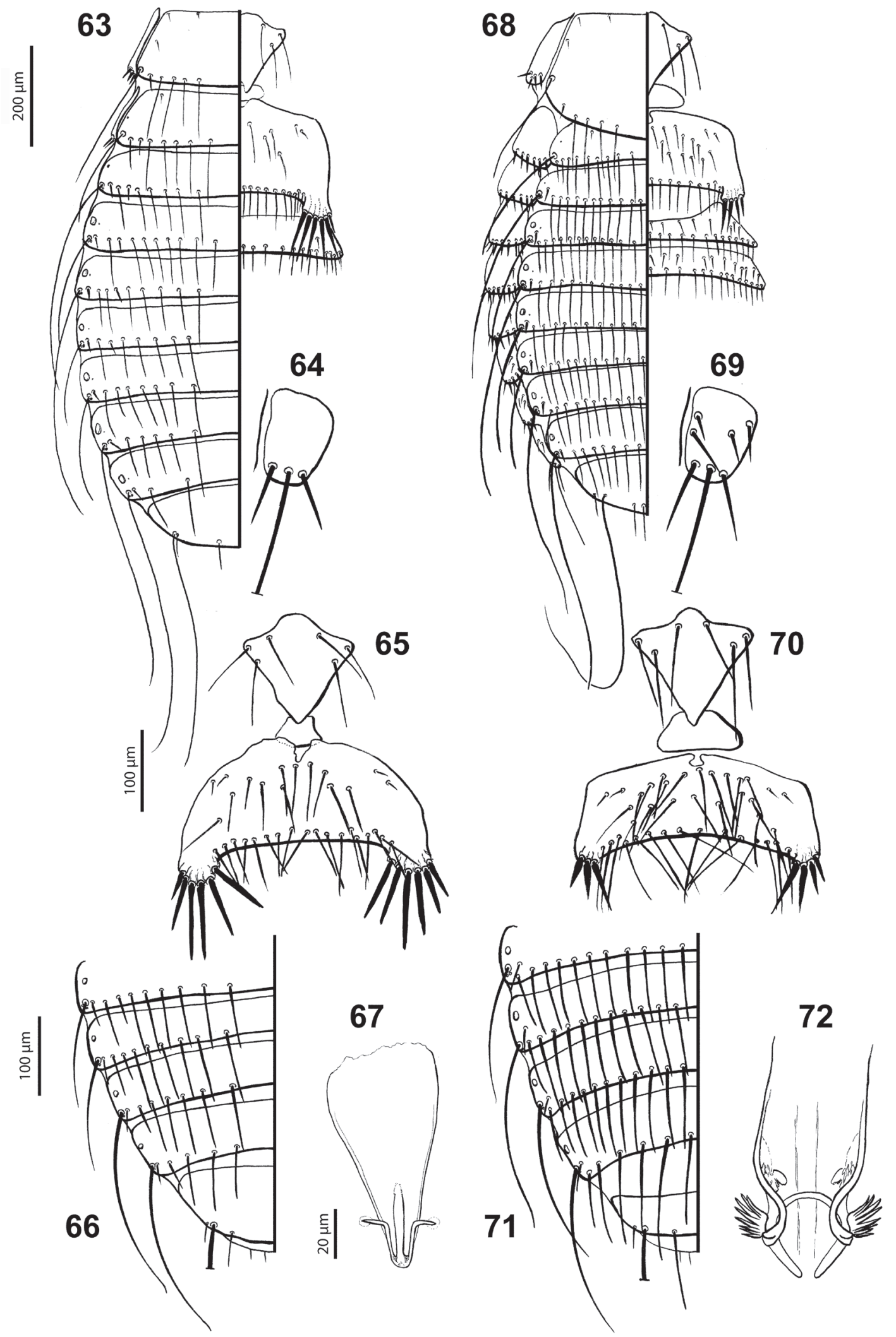

Figs. 63-67. Myrsidea faccioae sp. n. Figs. 68-72. M. lampropsaricola sp. n. Female metanotum and dorsal abdomen (63, 68). Pleurite VIII of female $(64,69)$. Metasternal, sternal I and II plates $(65,70)$. Tergites V-IX + X of male $(66,71)$. Male genital sclerite $(67,72)$. 
these louse specimens possible on the joint Museu Paraense Emilío Goeldi/Field Museum of Natural History Japurá expedition.

Diagnosis. Among the Myrsidea species which parasitise wrens, both sexes of this new species are morphologically close to Myrsidea whitemani Price, Johnson et Dalgleish, 2008 by having weakly developed hypopharyngeal sclerites. In both sexes the long length, reaching the posterior margin of sternite III, of the lateral spinelike setae on the asters of sternite II is distinctive (short in M. whitemani, no more than one very long internal spine); the postspiracular setae on segments I, III, V and VI are short (long in $M$. whitemani); and the smaller total length (1.68-1.81 in females, 1.46-1.49 in males of M. whitemani). The males have distinct genital sclerite with rounded posterior margin (incised in M. whitemani) and females have distinctly shaped sternite II (as long as wide, instead of wider than longer in $M$. whitemani). Also they have the tendency to present fewer setae on tergites VI (12-13 vs 18-20 in M. whitemani, 22-24 of Price et al. 2008a) and VII (5-9 vs 13-14 in M. whitemani, 17-18 of Price et al. 2008a).

\section{Species from Icteridae}

Major reviews: Clay (1968).

\section{Myrsidea lampropsaricola sp. n. Figs. 46, 47, 68-72}

Female. Habitus and head shape as in Fig. 46. Dorsal head seta 10, 0.039-0.044 long; dhs 11, 0.114-0.135 long, ratio dhs10/11 0.322-0.360. Hypopharynx reduced, ls5 0.09-0.13, ventrolateral fringe, 9 setae. Gula with 5 setae on each side (one paratype with 4 and 5 on each side). First tibia with 3 and 4 outer lateral ventral and dorsal setae, respectively. Mesonotum without median division. Metanotum with posterior margin concave, central portion surpassing up to middle of tergite I, with 12-13 setae on posterior margin, metasternal plate with 7-8 setae (as in Fig. 70). Setae of femoral brush, 14-16. Metanotum and abdomen as in Fig. 68. Tergites I-III roughly straight on posterior margin. Without median gap in each tergal setal row. Tergal setae: I, 21-22; II, 23-26; III, 21-27; IV, 20-27; V, 25-27; VI, 24-25; VII, 21-22; VIII, 15-16. Postspiracular setae shortest $(0.15-0.25)$ on I, III, V and VI, and long (0.38-0.47) on II, IV, VII and VIII.

Sternite III greatly arched and narrowed medially (Fig. 68). Anterior row of setae present on sternites. Sternal setae: I, 0; II, each aster of 4 setae, posterior margin with 16-20 and anteriorly with 26-29; III, 28-32 (16-18); IV, 26-30 (21-22); V, 27-33 (22-23); VI, 24-28 (23-26); VII, 15 (22-24); VIII-IX, 50-56; vulvar margin spiculated and with 15 setae. Each pleurite III-VII with about 5-8 short marginal setae; presence of 1-6 anterior setae on pleurites II-VII; pleurite VIII as in Fig. 69. Tergite IX with 2-4 inner posterior setae, on each side, 0.04-0.07 long. Anus with 36-38 ventral fringe setae, 41-45 dor- sal. Dimensions $(\mathrm{n}=3$ ): TW, 0.50-0.52; POW, 0.37; HL, 0.32-0.35; PW, 0.35-0.36; PSPL, 0.15; MW, 0.51-0.55; MSPL, 0.16-0.18; AWIV, 0.66-0.76; ANW, 0.25-0.26; TL, 1.58-1.69.

Male. Much as in female, habitus as in Fig. 47. Gular plate with 4-6 setae on each side. Metanotum with 8-9 setae on posterior margin. Setae of femoral brush, 12-15. Tergal setae: I, 15-19; II, 16-19; III, 19-20; IV, 18-23; V, 20-22; VI, 17-22; VII, 15-21; VIII, 12-13. Without median gap in each tergal setal row; tergal setae of similar length reaching alveoli of next tergal row. Postspiracular setae as for female. Pattern of chaetotaxy of tergites V-IX $+\mathrm{X}$ as in Fig. 71.

Anterior row of setae present on sternites. Sternal setae: I, 0; II, each aster of 2-4 setae, posterior margin with 15-16 and anteriorly with 20-21; III, 20-24 (13); IV, 26-28 (17-20); V, 23-27 (20-22); VI, 20-25 (22); VII, 13-19 (24); VIII, 30-39. Tergite IX with 1 inner posterior seta, on each side, 0.09 long. Anus with 8 internal setae on ventral side, and 3 on dorsal. Genital sac sclerite as in Fig. 72. Dimensions $(\mathrm{n}=3)$ : TW, 0.45-0.46; POW, 0.32-0.33; HL, 0.28-0.30; PW, 0.30-0.31; PSPL, 0.13; MW, 0.40-0.41; MSPL, 0.14-0.15; AWIV, 0.47-0.49; GL, 0.46-0.48; GSL, 0.10; TL, 1.39-1.42.

Ty p e host: Lampropsar tanagrinus (Spix) - velvet-fronted grackle (Icteridae).

Type loc a lity: Rio Acanauí, Município Japurá, Amazonas State, Brazil (0200'53"S; 66³9'56"W).

Ty pe materia 1: Holotype female (MZUSP 2342), ex Lampropsar tanagrinus, JAP366 MPEG 63237; Rio Acanauí, Município Japurá, Amazonas State, Brazil, 20 July 2007, collected by J.D. Weckstein. Paratypes: three males and two females, same data as the holotype. Coll. Nos.: one male (FMNH-INS 94016) and one female (FMNH-INS 94017, DNA voucher Mysp.Lata.1.4.2011.5); two males (MZUSP 2344, 2345) and one female (MZUSP 2343).

E t y m o log y: Composed by Lampropsar, the monotypic genus of the host; and -cola (= dwell in Latin).

Diagnosis. Morphologically close to $M$. psittaci Carriker, 1955 by the greatly reduced sitophore sclerite of the hypopharynx, absence of anterior tergal setae, reduced number of anterior pleural setae, and on males the inwardly projecting posterior arm of basal plate angulated (see Clay 1968). However, M. lampropsaricola sp. n. can be promptly distinguished by $M$. psittaci by the shape of genital sclerites in males and on females by the shape of the metanotum and tergite III.

\section{Phylogenetic and morphological analyses}

Molecular phylogenetic data are consistent with the morphological diagnosis of these ten new Myrsidea species. All ten of these new species are both genetically and phylogenetically distinct as shown in the maximum likelihood phylogram based on mtDNA COI sequences (Fig. 73). If one takes the tree at face value, without 


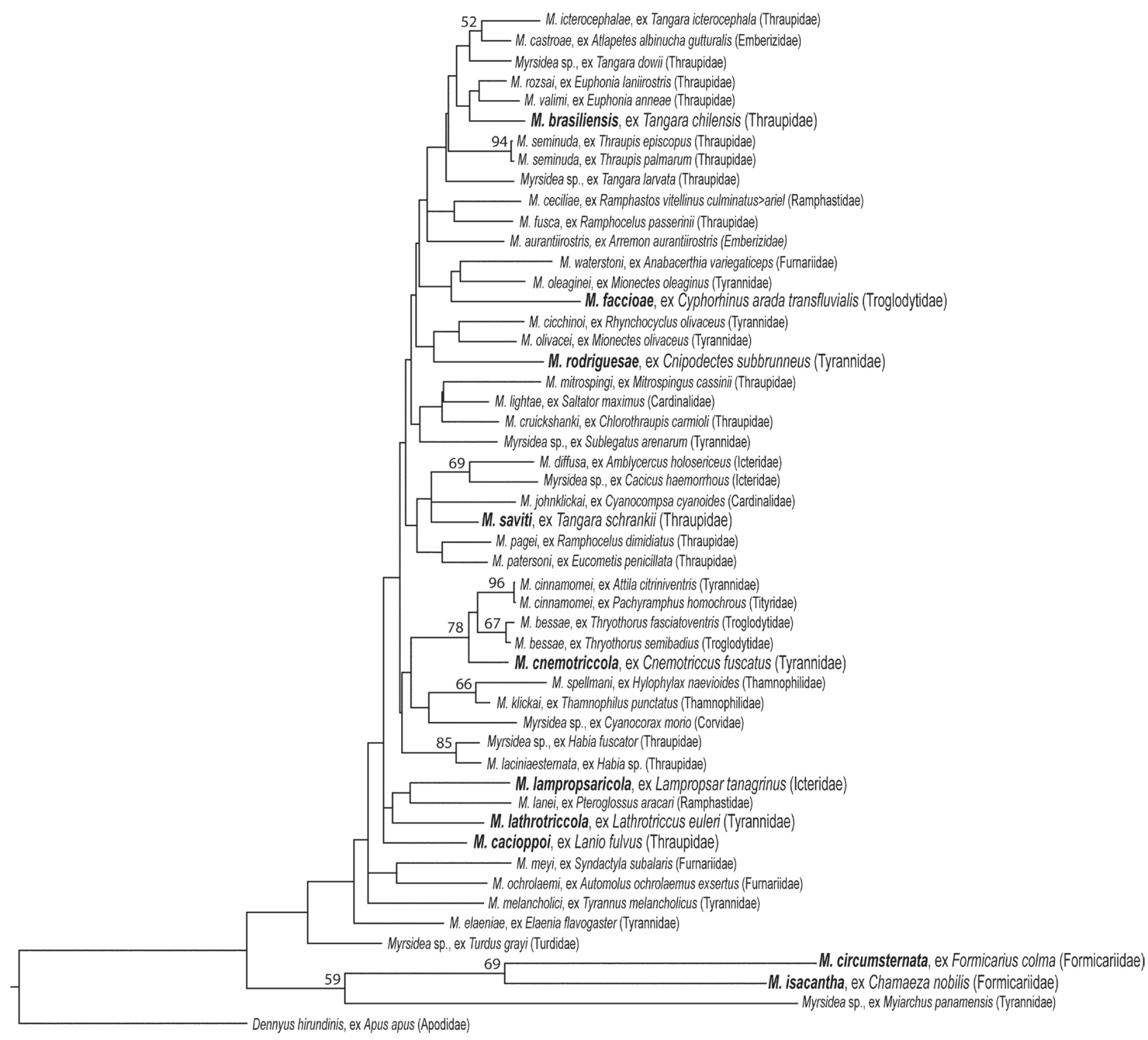

$0 . \overline{4 \text { substitutions/site }}$

Fig. 73. Best maximum likelihood phylogram of Neotropical Myrsidea taxa based on the mtDNA COI sequences. Numbers above nodes are maximum likelihood bootstrap support. Only support values greater than $50 \%$ are shown on the tree. New species described in the present paper are in bold type and bigger font.

considering the weak bootstrap support for many nodes, clades of closely related Myrsidea species tend to be from the same or closely related host families. Furthermore, most of the strongly supported nodes also group Myrsidea taxa found on the same or closely related host families. For example, M. brasiliensis comes out in a large but weakly supported clade of Myrsidea species parasitizing birds in the family Thraupidae.

One particularly interesting phylogenetic result is that the two newly described $M$. circumsternata and $M$. isacantha, which parasitise birds in the family Formicariidae, are well supported sister taxa and are phylogenetically distinct from nearly all other Myrsidea species, which matches their morphological distinctiveness (e.g. pres- ence of $d h s 23$ and $d p s 2$ ) and required us to broaden the set of diagnostic characters used to the define of the genus Myrsidea.

As defined by Clay $(1966,1969)$ one of the key characters that distinguishes the genus Myrsidea from other Menoponidae (e.g. Dennyus Neumann, 1906) is the absence of dorsal head seta 23 (sensu Clay 1969). Another defining character of the genus Myrsidea is the absence of central pronotal setae (dps 1 and 2) (Clay 1966), although three years later Clay (1969) presented data showing that some species of Myrsidea could have at least one pair of central pronotal setae (see couplet 32). The occipital setae (dhs 21 and 22) are present in all Menoponidae and their 
Table 1. Estimate of total known and unknown Brazilian Myrsidea species diversity based on an index of host specificity calculated from a list of perching birds (Passeriformes), hummingbirds (Trochilidae) and toucans (Ramphastidae) found in Brazil derived from the Howard and Moore (Dickinson 2003) checklist reported by Avibase (Lepage 2013).

\begin{tabular}{|c|c|c|c|c|c|c|c|c|c|c|}
\hline \multirow[b]{2}{*}{$\begin{array}{l}\text { Brazilian bird } \\
\text { families } \\
\text { parasitised } \\
\text { by Myrsidea }\end{array}$} & \multicolumn{4}{|c|}{ Known World fauna } & \multicolumn{2}{|c|}{$\begin{array}{l}\text { Potential Brazilian } \\
\text { fauna** }\end{array}$} & \multicolumn{4}{|c|}{ Brazilian fauna } \\
\hline & $\begin{array}{c}\text { Bird } \\
\text { species }\end{array}$ & $\begin{array}{c}\text { Myrsidea } \\
\text { species }\end{array}$ & $\begin{array}{c}\text { Host species } \\
\text { for } \\
\text { Myrsidea }\end{array}$ & IS* & $\begin{array}{c}\text { Myrsidea } \\
\text { species }\end{array}$ & $\begin{array}{c}\text { Host species } \\
\text { for } \\
\text { Myrsidea }\end{array}$ & $\begin{array}{c}\text { Bird } \\
\text { species } \\
* * *\end{array}$ & $\begin{array}{c}\text { Myrsidea } \\
\text { species }\end{array}$ & $\begin{array}{c}\text { Host species } \\
\text { for } \\
\text { Myrsidea }\end{array}$ & $\begin{array}{c}\text { Estimate of } \\
\text { Myrsidea } \\
\text { species in } \\
\text { Brazil**** }\end{array}$ \\
\hline Trochilidae & 331 & 3 & 3 & 1.00 & 1 & 1 & 80 & 0 & 0 & 80 \\
\hline Ramphastidae & 120 & 9 & 18 & 0.50 & 7 & 9 & 27 & 7 & 8 & 13 \\
\hline Pipridae & 48 & 4 & 3 & 1.33 & 3 & 2 & 35 & 2 & 2 & 47 \\
\hline Cotingidae & 96 & 2 & 2 & 1.00 & 1 & 1 & 53 & 0 & 0 & 53 \\
\hline Tyrannidae & 400 & 15 & 14 & 1.07 & 16 & 15 & 204 & 4 & 4 & 219 \\
\hline Thamnophilidae & 206 & 6 & 6 & 1.00 & 4 & 4 & 162 & 0 & 0 & 162 \\
\hline Formicariidae & 62 & 3 & 3 & 1.00 & 3 & 3 & 15 & 3 & 3 & 15 \\
\hline Furnariidae & 236 & 4 & 6 & 0.67 & 2 & 3 & 106 & 0 & 0 & 71 \\
\hline Dendrocolaptidae & 50 & 2 & 2 & 1.00 & 2 & 2 & 36 & 0 & 0 & 36 \\
\hline Corvidae & 117 & 66 & 56 & 1.18 & 1 & 1 & 8 & 1 & 1 & 9 \\
\hline Hirundinidae & 84 & 7 & 10 & 0.70 & 6 & 5 & 16 & 0 & 0 & 11 \\
\hline Troglodytidae & 76 & 4 & 4 & 1.00 & 1 & 1 & 17 & 1 & 1 & 17 \\
\hline Turdidae & 165 & 21 & 27 & 0.78 & 7 & 6 & 17 & 1 & 1 & 13 \\
\hline Estrildidae & 130 & 4 & 5 & 0.80 & 1 & 1 & 1 & 0 & 0 & 1 \\
\hline Icteridae & 98 & 10 & 18 & 0.56 & 7 & 8 & 37 & 3 & 3 & 21 \\
\hline Coerebidae & 1 & 1 & 1 & 1.00 & 1 & 1 & 1 & 0 & 0 & 1 \\
\hline Emberizidae & 308 & 16 & 16 & 1.00 & 6 & 6 & 73 & 2 & 2 & 73 \\
\hline Thraupidae & 202 & 31 & 32 & 0.97 & 18 & 19 & 78 & 5 & 5 & 76 \\
\hline Cardinalidae & 42 & 5 & 4 & 1.25 & 3 & 3 & 16 & 1 & 1 & 20 \\
\hline Parulidae & 114 & 4 & 4 & 1.00 & 2 & 2 & 22 & 0 & 0 & 22 \\
\hline Fringillidae & 168 & 5 & 8 & 0.63 & 2 & 3 & 4 & 0 & 0 & 2 \\
\hline Total & 3054 & 222 & 242 & 0.93 & 94 & 96 & 1008 & 30 & 31 & 962 \\
\hline
\end{tabular}

*Index of specificity (IS) = Myrsidea species / host species of Myrsidea; IS = 1; high specificity; IS < 1; low specificity, one Myrsidea species parasitises many host species; IS > 1; some cases of duplication (or secondary infestation) leads to one host species being parasitised by multiple Myrsidea species; **based on host association data of Myrsidea from Dalgleish and Price 2003, Price et al. 2003, 2004, 2005, 2008a,b,c, Price and Dalgleish 2006, Price and Johnson 2009, Sychra et al. 2009, Kounek et al. 2011a,b; ***the total value does not include 19 incertae sedis host species for which there are no Myrsidea records and thus this a slight underestimate; ****estimate of Myrsidea species in Brazil $=$ bird species in Brazil $\times$ index of specificity.

relative length and thickness may provide specific or generic characters (Clay 1969).

In addition to other generic characters for the genus, Clay (1966) suggested that the small size of the outer occipital setae (dhs 22) of Myrsidea could be diagnostic for the genus. This is true for Myrsidea from other species groups examined by us, including material from a variety of host families (ex Cardinalidae, Corvidae, Dendrocolaptidae, Emberizidae, Hirundinidae, Icteridae, Ramphastidae, Thraupidae, Trochilidae, Troglodytidae, Turdidae, Tyrannidae, Tityridae), which all have a very short $d h s 22$. However, in the species from Formicariidae, the $d h s 22$ is as long as the $d h s 21$ (as noted by Sychra et al. 2006).

Nevertheless, instead of erecting a new generic name for these three taxa, we have opted to broaden the definition of the genus Myrsidea as having dhs22 short or long and $d h s 23$ absent or rarely present (Fig. 12). These generic limits are conservatively provisional until a large systematic study involving morphological and molecular data, including additional material from the Formicariidae, has been undertaken to better characterize morphological features that define groups in this speciose chewing louse genus. However, for the most part, named Myrsidea species and unnamed ones can still be generically placed in Myrsidea using the generic key presented by Clay (1969) and the key for genera found on Passeriformes by Price et al. (2003).

The phylogenetic results also suggest that $M$. icterocephalae and M. brasiliensis, two members of the bonariensis species group as defined by Price and Dalgleish (2006), are phylogenetically in the same clade, although bootstrap support for these relationships is weak. However, morphologically defined members of the fusca species group, also defined by Price and Dalgleish (2006), do not necessarily come out as close relatives in the tree presented here, perhaps because many relationships in this tree are not strongly supported. Therefore, additional data are likely to move many of the taxa around and one important focus of future work on Myrsidea should be to collect additional molecular data and test the monophyly of groups defined by morphological features.

Lastly, nearly all of the Myrsidea species analysed here using both morphology and molecular data are extremely host specific. Exceptions indicated by both morphologi- 
cal and molecular analysis include $M$. seminuda, which parasitises Thraupis episcopus and T. palmarum, M. bessae, which parasitises Thryothorus fasciatoventris and T. semibadius, and M. cinnamomei, which parasitises three hosts in two different, but somewhat related host families, Attila citriniventris, Pachyramphus homochrous and $P$. cinnamomeus. Interestingly, two of these 'host generalist' Myrsidea, M. bessae and M. cinnamomei, are phylogenetically closely related (Fig. 73) and thus, perhaps, there is something about this clade of Myrsidea that allows them to parasitise multiple suboscine (suborder Tyranni) host species. Future analyses of host specificity (similar to those by Johnson et al. 2009, 2011) in a larger phylogenetic context could clarify this pattern.

\section{Estimate of Brazilian Myrsidea species diversity}

Our analysis (see Table 1) of published Myrsidea host association records (Clay 1968, Dalgleish and Price 2003, Price et al. 2003, 2004, 2005, 2008a-c, Price and Dalgleish 2006, Price and Johnson 2009, Sychra et al. 2009) with reference to the Howard and Moore (Dickinson 2003) checklist of birds from Brazil reported by Avibase produced an estimate of the potential number of described Myrsidea species found on avian hosts known from Brazil (90 species) and an estimate of the total number of Myrsidea species given levels of host specificity and the total number of bird species found in Brazil from avian families known to host Myrsidea (ca 940 species).

Our extrapolated estimate of the number of Myrsidea species that should be in Brazil is approximately one order of magnitude greater than the potential number of named Myrsidea species from Brazil (90) and more than one order of magnitude greater than the number of described Myrsidea species known from Brazil (19 plus the 10 described in this paper $=29$ species). Our extrapolation suggests that given our understanding of Myrsidea host specificity and the diversity of Brazilian birds, nearly 930 unnamed Myrsidea species are in need of discovery, study and description. Furthermore, if one puts this estimate into the context of overall louse diversity in Brazil, which has ca 470 known species of Phthiraptera (M.P. Valim - unpublished data), our result is even more staggering. Essentially, there may be nearly twice as many Myrsidea species waiting to be described from Brazilian birds than there are named Phthiraptera taxa known from Brazil so far.

Furthermore, from a worldwide perspective, the Brazilian estimate is more than two times the total worldwide number of Myrsidea species ( ca 350) described thus far (Sychra 2010, Valim et al. 2011). Therefore, the ten new species described here are only a drop in the bucket of Myrsidea species diversity in Brazil and on the planet. We have only begun to understand this megadiverse parasite group and this estimate clearly underscores the importance of the critical first steps, taxonomic description and phylogenetic analysis, to understanding the biodiversity of megadiverse parasite groups such as the louse genus Myrsidea.

\section{Checklist for the species of Myrsidea recorded in Brazil. Records are based on Brazilian states.}

1. Myrsidea abbreviata Eichler, 1951

Host: Ramphastos dicolorus Linnaeus

(Piciformes: Ramphastidae)

Record: Santa Catarina

Reference: Eichler (1951: 50), Price et al. (2004: 11)

2. Myrsidea aleixoi Price, Hellenthal et Weckstein, 2004

Host: Pteroglossus beauharnaesii Wagler

(Piciformes: Ramphastidae)

Record: Mato Grosso

Reference: Price et al. (2004: 13)

3. Myrsidea andyolsoni Dalgleish et Price, 2003

Host: Heterocercas linteatus (Strickland)

(Passeriformes: Pipridae)

Record: Brazil (no precise locality)

Reference: Dalgleish and Price (2003: 171)

4. Myrsidea brasiliensis sp. $\mathbf{n}$.

Host: Tangara chilensis

Record: Amazonas

Reference: Present study (2013: 386)

5. Myrsidea cacioppoi sp. $\mathbf{n}$.

Host: Lanio fulvus

Record: Amazonas

Reference: Present study (2013: 384)

6. Myrsidea ceciliae Carriker et Díaz-Ungría, 1961

Hosts: Ramphastos vitellinus culminatus Gould

and Ramphastos vitellinus ariel Vigors

Records: Amazonas, Mato Grosso, Pará

and São Paulo

Reference: Price et al. (2004: 5, 6)

7. Myrsidea cinnamomei Dalgleish et Price, 2005

Host: Attila citriniventris

Record: Amazonas

Reference: Present study (2013: 387)

8. Myrsidea circumsternata sp. $\mathbf{n}$.

Host: Formicarius colma

Record: Amazonas

Reference: Present study (2013: 383)

9. Myrsidea cnemotriccola sp. $\mathbf{n}$.

Host: Cnemotriccus fuscatus

Record: Amazonas

Reference: Present study (2013: 389)

10. Myrsidea coronatae Price et Dalgleish, 2007

Host: Paroaria capitata (Orbigny et Lafresnaye)

(Passeriformes: Emberizidae)

Record: Mato Grosso do Sul

Reference: Sychra et al. (2009: 501)

11. Myrsidea dorotheae Eichler, 1953

Host: Pteroglossus inscriptus humboldti Wagler

Record: Amazonas

Reference: Price et al. $(2004: 5,6)$ 
12. Myrsidea downsi Clay, 1968

Host: Psarocolius decumanus (Pallas)

(Passeriformes: Icteridae)

Record: Brazil (no precise locality)

Reference: Clay (1968: 218).

13. Myrsidea edgarsmithi Dalgleish et Price, 2003

Host: Pipra erythrocephala (Linnaeus)

(Passeriformes: Pipridae)

Record: Brazil (no precise locality)

Reference: Dalgleish and Price (2003: 170)

14. Myrsidea elegans Ansari, 1956

Host: Turdus rufiventris Vieillot

(Passeriformes: Turdidae)

Localities: Rio de Janeiro and Rio Grande do Sul

References: Valim and Serra-Freire (2003: 155);

Valim et al. (2009: 252)

Remarks. The specimens reported by Valim and Serra-Freire (2003) are most likely an undescribed species of Myrsidea, representing a second record of this louse genus on Turdus rufiventris (M.P. Valim unpublished data)

15. Myrsidea extranea (Carriker, 1903)

Host: Ramphastos tucanus cuvieri Wagler

Records: Amazonas and Mato Grosso

Reference: Price et al. (2004: 8)

16. Myrsidea faccioae sp. $\mathbf{n}$.

Host: Cyphorhinus arada transfluvialis (Todd)

Record: Amazonas

Reference: Present study (2013: 392)

17. Myrsidea fallax Kéler, 1938

Host: Cyanocorax cyanomelas (Vieillot)

Record: Mato Grosso

Reference: Oniki (1999: 189)

18. Myrsidea isacantha sp. $\mathbf{n}$.

Host: Chamaeza nobilis

Record: Amazonas

Reference: Present study (2013: 381)

19. Myrsidea lampropsaricola sp. $\mathbf{n}$.

Host: Lampropsar tanagrinus

Record: Amazonas

Reference: Present study (2013: 394)

20. Myrsidea lanei Price, Hellenthal et Weckstein, 2004

Host: Pteroglossus aracari (Linnaeus)

Record: Pará

Reference: Price et al. (2004: 13)

21. Myrsidea lathrotriccola sp. $\mathbf{n}$.

Host: Lathrotriccus euleri

Record: Amazonas

Reference: Present study (2013: 391)

22. Myrsidea lightae Price, Johnson et Dalgleish, 2008

Host: Saltator maximus (Müller)

(Passeriformes: Cardinalidae)

Record: Tocantins

Reference: Enout et al. (2012: 1734)
23. Myrsidea picta Carriker, 1955

Host: Cacicus cela cela (Linnaeus)

(Passeriformes: Icteridae)

Record: 'Brazil Village' (no precise locality)

Reference: Clay (1968: 212)

24. Myrsidea ramphoceli Price et Dalgleish, 2006

Host: Ramphocelus carbo (Pallas)

(Passeriformes: Thraupidae)

Records: Mato Grosso do Sul and Tocantins

References: Sychra et al. (2009: 502);

Enout et al. (2012: 1735)

25. Myrsidea rodriguesae sp. $\mathbf{n}$.

Host: Cnipodectes subbrunneus

Record: Amazonas

Reference: Present study (2013: 389)

26. Myrsidea saviti sp. $\mathbf{n}$.

Host: Tangara schrankii

Record: Amazonas

Reference: Present study (2013: 386)

27. Myrsidea seminuda Eichler, 1951

Host: Thraupis sayaca (Linnaeus)

(Passeriformes: Thraupidae)

Records: Mato Grosso do Sul and Tocantins

References: Sychra et al. (2009: 502);

Enout et al. (2012: 1735)

28. Myrsidea taciturni Price et Dalgleish, 2007

Host: Arremon taciturnus (Hermann)

(Passeriformes: Emberizidae)

Record: Tocantins

Reference: Enout et al. (2012: 1735)

29. Myrsidea witti Price, Hellenthal et Weckstein, 2004

Host: Ramphastos toco toco Statius Müller

Records: Amapá and Pará

Reference: Price et al. (2004: 7)

Acknowledgements. We thank Alexandre Aleixo (Museu Paraense Emílio Goeldi, Belém, Brazil), Shannon Hackett and John Bates (FMNH) for support and assistance during fieldwork, collection of the data presented herein, or both. We also thank Petra Sierwald, who made her National Science FoundationPartnerships for Enhancing Expertise in Taxonomy-funded microscope available for our use. This work was supported in part by the Conselho Nacional de Desenvolvimento Científico e Tecnólogico, Brazil with a postdoctoral fellowship 200453/2010-6 to M.P.V. and the FAPESP - São Paulo Research Foundation 2011/11420-5 and 2012/06951-4 to M.P.V.; National Science Foundation grants DEB-0515672 and DEB-1120054 to J.D.W., and the FMNH's Emerging Pathogens Project, funded by the Davee Foundation and the Dr. Ralph and Marian Falk Medical Research Trust. DNA sequencing was carried out at FMNH's Pritzker Laboratory for Molecular Systematics and Evolution, operated with support of the Pritzker Foundation. We are grateful to Oldřich Sychra and one anonymous referee who provided useful comments that improved the final version of this paper. 
Atkinson C.T., Thomas N.J., Hunter D.B. 2008: Parasitic Diseases of Wild Birds. Wiley-Blackwell, Ames, Iowa, 595 pp.

Bueter C., Weckstein J.D., Johnson K.P., Bates J.M., Gordon, C.E. 2009: Comparative phylogenetic histories of two louse genera found on Catharus thrushes and other birds. J. Parasitol. 95: 295-307.

Clay T. 1966: Contributions towards a revision of Myrsidea Waterston. I. (Menoponidae: Mallophaga). Bull. Br. Mus. Nat. Hist. Entomol. 17: 327-395.

Clay T. 1968: Contributions towards a revision of Myrsidea Waterston. III. (Menoponidae: Mallophaga). Bull. Br. Mus. Nat. Hist. Entomol. 21: 205-243.

Clay T. 1969: A key to the genera of the Menoponidae (Amblycera: Mallophaga: Insecta). Bull. Br. Mus. Nat. Hist. Entomol. 24: 3-26.

Clay T. 1970: The Amblycera (Phthiraptera: Insecta). Bull. Br. Mus. Nat. Hist. Entomol. 25: 75-98.

Clayton D.H., Drown D.M. 2001: Critical evaluation of five methods for quantifying chewing lice (Insecta: Phthiraptera). J. Parasitol. 87: 1291-1300.

Clayton D.H., Gregory R.D., Price R.D. 1992: Comparative ecology of Neotropical bird lice (Insecta: Phthiraptera). J. Anim. Ecol. 61: 781-795.

Combes C. 1996: Parasites, biodiversity and ecosystem stability. Biodiversity Conserv. 5: 953-962.

Combes C., Hudson P., Hochberg M. 1996: Host-parasite coevolution. Biodiversity Conserv. 5: 951.

Dalgleish R.C., Price R.D. 2003: Four new species of Myrsidea (Phthiraptera: Menoponidae) from manakins (Passeriformes: Pipridae). J. N. Y. Entomol. Soc. 111: 167-173.

Dickinson E.C. (Ed.) 2003: The Howard and Moore Complete Checklist of the Birds of the World. Third Edition. Princeton University Press, New Jersey, 1039 pp.

EIChLER W. 1951: Notulae Mallophagologicae. XVII. Die Myrsideen. Zool. Anz. 146: 45-53.

Enout A.M.J., Lobato D.N., Azevedo C.S., Antonini Y. 2009: Parasitismo por malófagos (Insecta) e ácaros (Acari) em Turdus leucomelas (Aves) nas estações reprodutiva e de muda de penas no Parque Estadual do Rio Preto, Minas Gerais, Brasil. Zoologia 26: 534-540.

Enout A.M.J., Lobato D.N., Diniz F.C., Antonini Y. 2012: Chewing lice (Insecta, Phthiraptera) and feather mites (Acari, Astigmata) associated with birds of the Cerrado in Central Brazil. Parasitol Res. 111: 1731-1742.

Guimarães L.R. 1944: Ectoparasitos de aves e mamiferos colecionados em Monte Alegre. Pap. Avulsos Zool. 6: 15-20.

Guindon S., Gascuel O. 2003: A simple, fast, and accurate algorithm to estimate large phylogenies by maximum likelihood. Syst. Biol. 52: 696-704.

Johnson K.P., Cruickshank R.H., Adams R.J., Smith V.S., Page R.D.M., Clayton D.H. 2003: Dramatically elevated rate of mitochondrial substitution in lice (Insecta: Phthiraptera). Mol. Phylogenet. Evol. 26: 231-242.

Johnson K.P., Malenke J.R., Clayton D.H. 2009: Competition promotes the evolution of host generalists in obligate parasites. Proc. R. Soc. Lond. B. Biol. sci. 276: 3921-3926.

Johnson K.P., Price R.D. 2009: Five new species of Myrsidea Waterston (Phthiraptera: Menoponidae) from tanagers (Passeriformes: Thraupidae) in Panama. Zootaxa 2200: 61-68.
Johnson K.P., Weckstein J.D., Bush S.E., Clayton D.H. 2011: The evolution of host specificity in dove body lice. Parasitology 138: $1730-1736$.

Kounek F., Sychra O., Čapek M., Lipková A., Literák, I. 2011a: Chewing lice of the genus Myrsidea (Phthiraptera: Menoponidae) from the Cardinalidae, Emberizidae, Fringillidae and Thraupidae (Aves: Passeriformes) from Costa Rica, with descriptions of four new species. Zootaxa 3032: 1-16.

Kounek F., Sychra O., Čapek M., Literák I. 2011b: Chewing lice of the genus Myrsidea (Phthiraptera: Menoponidae) from New World warblers (Passeriformes: Parulidae) from Costa Rica, with descriptions of four new species. Zootaxa 3137: $56-63$.

Lepage D. (Ed.) 2013: Avibase-the world bird database. World Wide Web publication, www.avibase.bsc-eoc.org, 06/2012.

de Meeûs T., Michalakis Y., Renaud F. 1998: Santa Rosalia revisited: or why are there so many kinds of parasites in 'the garden of earthly delights'? Parasitol. Today 14: 10-13.

de Meeûs T., Renaud F. 2002: Parasites within the new phylogeny of eukaryotes. Trends Parasitol. 18: 247-251.

Ohlson J.I., FJeldSÅ J., ERICSON P.G.P. 2007a: Tyrant flycatchers coming out in the open: phylogeny and ecological radiation of Tyrannidae (Aves: Passeriformes). Zool. Scr. 37: 315-335.

Ohlson J.I., Prum R.O., Ericson P.G.P. 2007b: A molecular phylogeny of the cotingas (Aves: Cotingidae). Mol. Phylogenet. Evol. 42: 25-37.

ONIKI Y. 1990: Survey of lice (Mallophaga) and some remarks on their life cycles on birds at Balbina, Amazonas, Brazil. Rev. Bras. Biol. 50: 615-617.

ONIKI Y. 1999: Avian parasites and notes on habits of lice from Mato Grosso, Brazil. Iheringia, Zool. 86: 183-190.

Palma R.L. 1978: Slide mounting of lice: a detailed description of the Canada balsam technique. N. Z. Entomol. 6: 432-436.

Parker P.G., Whiteman N.K., Miller R.E. 2006: Conservation medicine on the Galápagos islands: partnerships among behavioral, population, and veterinary scientists. Auk 123: 625-638.

Posada D. 2008: jModelTest: Phylogenetic Model Averaging. Mol. Biol. Evol. 25: 1253-1256.

Price P.W. 1980: Evolutionary Biology of Parasites. Princeton University Press, Princeton, New Jersey, 237 pp.

Price R.D., Dalgleish R.C. 2006: Myrsidea Waterston (Phthiraptera: Menoponidae) from tanagers (Passeriformes: Thraupidae), with descriptions of 18 new species. Zootaxa 1174: $1-25$.

Price R.D., Hellenthal R.A., Dalgleish R.C. 2005: The genus Myrsidea Waterston (Phthiraptera: Menoponidae) from tyrantflycatchers (Passeriformes: Tyrannidae), with descriptions of 13 new species. Zootaxa 1048: 1-20.

Price R.D., Hellenthal R.A., Palma R.L. 2003: World checklist of chewing lice with host associations and keys to families and genera. In: R.D. Price, R.A. Hellenthal, R.L. Palma, K.P. Johnson and D.H. Clayton (Eds.), The Chewing Lice: World Checklist and Biological Overview, Illinois Nat. Hist. Surv. Spec. Publ. 24, 448 pp.

Price R.D., Hellenthal R.A., Weckstein J.D. 2004: The genus Myrsidea Waterston (Phthiraptera: Menoponidae) from the toucans (Piciformes: Ramphastidae), with descriptions of three new species. Zootaxa 613: 1-18. 
Price R.D., Johnson K.P. 2009: Five new species of Myrsidea Waterston (Phthiraptera: Menoponidae) from tanagers (Passeriformes: Thraupidae) in Panama. Zootaxa 2200: 61-68.

Price R.D., Johnson K.P., Dalgleish R.C. 2008a: Myrsidea Waterston (Phthiraptera: Menoponidae) from wrens (Passeriformes: Troglodytidae), with descriptions of three new species. Zootaxa 1740: 59-65.

Price R.D., Johnson K.P., Dalgleish. R.C. 2008b: Five new species of Myrsidea Waterston (Phthiraptera: Menoponidae) from antshrikes and antbirds (Passeriformes: Thamnophilidae). Zootaxa 1819: 55-62.

Price R.D., Johnson K.P., Dalgleish R.C. 2008c: Five new species of Myrsidea Waterston (Phthiraptera: Menoponidae) from saltators and grosbeaks (Passeriformes: Cardinalidae). Zootaxa 1873: 1-10.

Swofford D.L. 2003: PAUP*: Phylogenetic analysis using parsimony (*and other methods), version 4. Sinauer, Sunderland, Massachusetts.

Sychra O. 2010: Myrsidea Waterston 1915 (Amblycera: Menoponidae). Abstracts from the Fourth International Conference on Phthiraptera (ICP4), Urgup, Turkey. Türkiye Parazitoloji Dergisi 34 (Suppl. 1): 34.

Sychra O., Literák I., ČApeK M. 2009: Chewing lice of the genus Myrsidea Waterston (Phthiraptera: Menoponidae) from the Emberizidae and Thraupidae (Passeriformes) in Mato Grosso do Sul, Brazil. Neotrop. Entomol. 38: 501-503.

Sychra O., Literák I., Čapek M., Havlíček M. 2006: Chewing lice (Phthiraptera) from typical antbirds and ground antbirds (Passeriformes: Thamnophilidae, Formicariidae) from Costa Rica, with descriptions of three new species of the genera Formicaphagus and Myrsidea. Zootaxa 1206: 47-61.

Received 16 January 2013
Timm R.M., Clauson B.L. 1987: Coevolution: Mammalia. In: McGraw-Hill Yearbook of Science and Technology. McGrawHill Book Company, New York, pp. 212-214

Valim M.P., Lambrecht F.M., Vianna E.E.S. 2009: New records of chewing lice (Insecta, Phthiraptera) from birds of southern Brazil, with description of a new species. Iheringia. Série Zool. 99: 249-258.

Valim M.P., Price R.D., Johnson K.P. 2011: New host records and descriptions of five new species of Myrsidea Waterston chewing lice (Phthiraptera: Menoponidae) from passerines (Aves: Passeriformes). Zootaxa 3097: 1-19.

Valim M.P., Serra-Freire N.M. 2003: Novos registros de Amblycera e Ischnocera (Phthiraptera) em Turdus rufiventris (Vieillot, 1818) no município de Silva Jardim, Rio de Janeiro, Brasil. Lundiana 4: 155-156.

Valim M.P., Teixeira R.H.F., Amorim M., Serra-Freire N.M. 2005: Malófagos (Phthiraptera) recolhidos de aves silvestres no Zoológico de São Paulo, SP, Brasil. Rev. Bras. Entomol. 49: 584-587.

Valim M.P., Weckstein J.D. 2011: Two new species of Brueelia Kéler, 1936 (Ischnocera, Philopteridae) parasitic on trogons (Aves, Trogoniformes) in Brazil. Zookeys 128: 1-13.

Windsor D.A. 1998: Most of the species on earth are parasites. Int. J. Parasitol. 28: 1939-1941.

ZwICKL D.J. 2006: Genetic algorithm approaches for the phylogenetic analysis of large biological sequence datasets under the maximum likelihood criterion. Ph.D. dissertation, The University of Texas at Austin, $115 \mathrm{pp}$.

Accepted 24 May 2013 